University of Massachusetts Amherst

ScholarWorks@UMass Amherst

Open Access Dissertations

$9-2012$

\title{
The Valuation Impact of Sec Enforcement Actions on Non-Target Foreign Firms
}

Roger Nelson Silvers

University of Massachusetts Amherst

Follow this and additional works at: https://scholarworks.umass.edu/open_access_dissertations

Part of the Management Information Systems Commons

\section{Recommended Citation}

Silvers, Roger Nelson, "The Valuation Impact of Sec Enforcement Actions on Non-Target Foreign Firms" (2012). Open Access Dissertations. 624.

https://doi.org/10.7275/3527586 https://scholarworks.umass.edu/open_access_dissertations/624

This Open Access Dissertation is brought to you for free and open access by ScholarWorks@UMass Amherst. It has been accepted for inclusion in Open Access Dissertations by an authorized administrator of ScholarWorks@UMass Amherst. For more information, please contact scholarworks@library.umass.edu. 
THE VALUATION IMPACT OF SEC ENFORCEMENT ACTIONS

ON NON-TARGET FOREIGN FIRMS

A Dissertation Presented

by

ROGER NELSON SILVERS

Submitted to the Graduate School of the University of Massachusetts Amherst in partial fulfillment of the requirements for the degree of

DOCTOR OF PHILOSOPHY

September 2012

Isenberg School of Management 
(C) Copyright by Roger Nelson Silvers 2012

All Rights Reserved 


\title{
THE VALUATION IMPACT OF SEC ENFORCEMENT ACTIONS ON NON-TARGET FOREIGN FIRMS
}

\author{
A Dissertation Presented \\ by \\ ROGER NELSON SILVERS
}

Approved as to style and content by:

Pieter Elgers, Chair

Mark Bradshaw, Member

Ben Branch, Member

Craig Doidge, Member

Bing Liang, Member

D. Anthony Butterfield, Ph.D. Program Director Isenberg School of Management 


\section{ACKNOWLEDGMENTS}

There are several people who have contributed to this manuscript, my professional development, and my life during this program. Because he fits all three criteria, I would first like to thank my advisor, Pieter Elgers. Pieter’s brilliance inspired me to explore a path that was risky, uncharted, and at times arduous. The choice is one I've never regretted. Pieter offered me the freedom to explore my own research interests and each step of the way he has been gracious and supportive.

Assembling a committee to support my chosen research domain at UMass required soliciting experts from outside of the department and outside of the school. Little did I know that the committee would turn out to be the "Dream Team.” I met Mark Bradshaw at the doctoral consortium in Lake Tahoe when a group of us went out for a run. Between our gasps of thin mountain air, I talked to Mark about my research and he was very positive and inspiring. Mark took a personal interest in helping me develop, often staying up until the early hours of the morning to provide comments and suggestions. Craig Doidge was incredibly kind to join the committee from a different university and also very generous with his time. Craig provided very valuable suggestions that shaped the manuscript and really provided insight into the research process. The commitment to my development by both Craig and Mark has been a highlight of my experience at UMass. I also thank Ben Branch and Bing Liang for their oversight during the proposal and defense phase of the Ph.D. program. Each committee member has motivated me to give more, and continually improve my research. My paper, research abilities, and career have all benefitted from committee insights and suggestions and working alongside each of them has been an incredible honor. 
I thank Chris Agoglia for his guidance, mentorship, and friendship throughout the PhD program. I also thank Tamara Lambert, Tom Kida, Jim Smith, Steve Perreault, Aaron Saiewitz, Ryan Guggenmos, Elisa Lee, and many friends at ISOM for their support.

Finally, I thank my wife, Angela, and my family for their sacrifice and encouragement over the past four years. Through the challenging times during the program and trying times of life they have carried me through. 


\section{ABSTRACT \\ THE VALUATION IMPACT OF SEC ENFORCEMENT ACTIONS ON NON-TARGET FOREIGN FIRMS \\ ROGER NELSON SILVERS \\ B.A., LYNCHBURG COLLEGE \\ Ph.D., UNIVERSITY OF MASSACHUSETTS AMHERST \\ Directed by: Professor Pieter Elgers}

This study provides a test of the market valuation impact of Securities and Exchange Commission (SEC) enforcement actions for foreign firms. I examine the SEC enforcement policy towards foreign firms under its jurisdiction. In contrast to Siegel (2005) who examines earlier years, I find that the SEC’s current (post-2002) enforcement intensity is considerable and has increased dramatically by comparison. I construct a novel test using the burgeoning series SEC enforcement events as changes to the legal environment that circumvents the issues associated with firm-level exchange-listing events (e.g. self-selection and simultaneous changes to firm traits). The tests focus on stock returns of foreign firms not targeted by the SEC during event windows surrounding SEC announcements of enforcements against foreign firms. This isolates the effect of a changing enforcement environment. I find that when the SEC takes action against a foreign firm, non-target foreign firms experience positive stock returns. Returns are amplified for firms from weaker home legal environments, suggesting that the returns are due to a perceived increase in SEC scrutiny. Finally, consistent with the market adjusting to the new enforcement regime, the magnitude of non-target firm returns declines with each sequential SEC enforcement action. The overall results provide evidence that SEC 
oversight plays a significant role in increasing the value of foreign firms, which supports the legal bonding hypothesis discussed in prior literature. 


\section{TABLE OF CONTENTS}

\section{Page}

ACKNOWLEDGMENTS iv

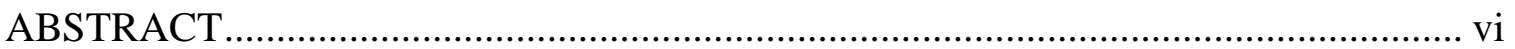

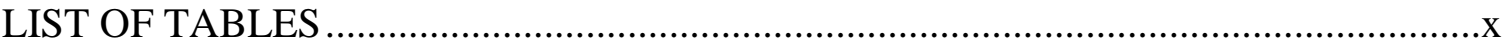

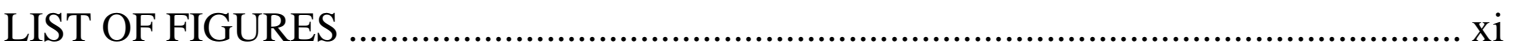

\section{CHAPTER}

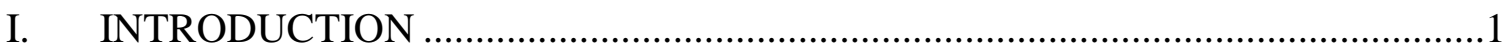

Challenges Facing Enforcement Research................................................. 1

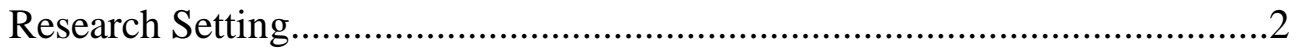

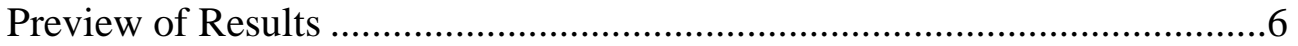

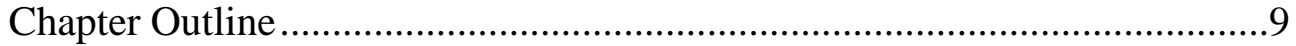

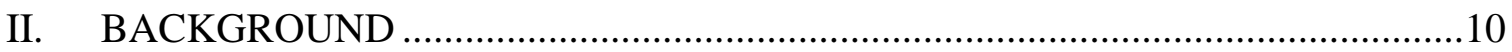

Effects of Regulation on Foreign Firms....................................................10

Capital Market Consequences of Enforcement.............................................11

Changes in the Enforcement Environment ................................................12

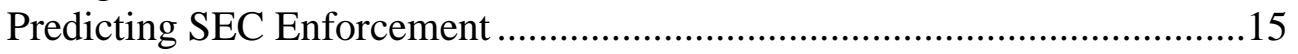

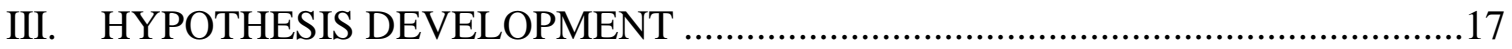

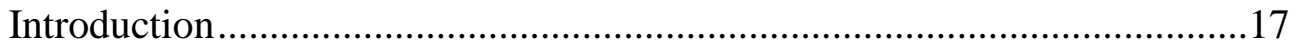

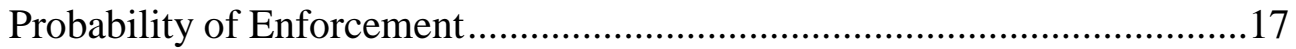

Valuation Effects of Enforcement ...............................................................18

Return Conditioning Effects of Home Country Oversight ..........................20

Intertemporal Return Magnitudes ............................................................21

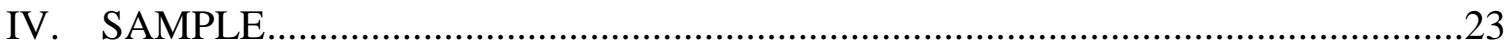

Enforcement Sample ................................................................................23

Universe of Foreign SEC-regulated Firms ...............................................25

Non-Target Sample.........................................................................26

V. RESEARCH DESIGN AND EMPIRICAL RESULTS .........................................28 
Probability of SEC Enforcement ................................................................28

Portfolio Abnormal Return Analysis ........................................................30

Panel Regression Analyses of Firm-specific Abnormal Returns....................33

Panel Regression Analyses of Home Country Strength on Event Return

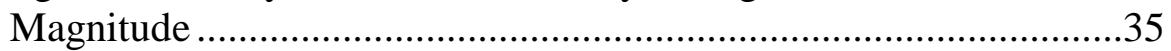

Intertemporal Effect of Enforcement Events on Return Magnitude..............37

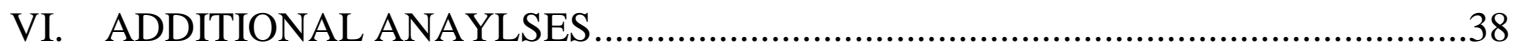

Confounds Affecting the Intertemporal Relation between Enforcement Events and Return Magnitude........................................................38

Alternatives to Increased Oversight.................................................................39

Response Dynamics: Contagion/Competitive Effects ...................................42

An Enforcement Based Trading Strategy ......................................................43

Other Robustness Checks ...........................................................................44

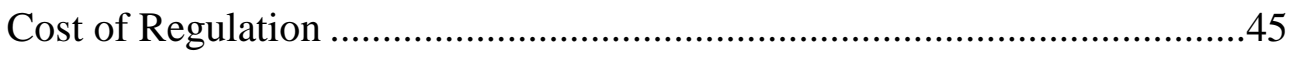

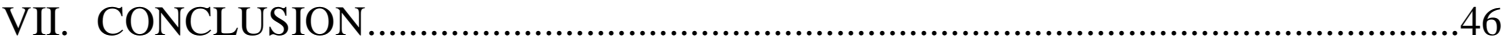

APPENDICES

A: VARIABLE DEFINITIONS AND MODEL SPECIFICATION .............49

B: CAPITALIZATION RATE ESTIMATION ............................................51

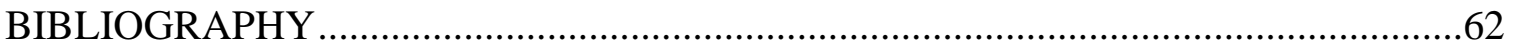




\section{LIST OF TABLES}

Table

Page

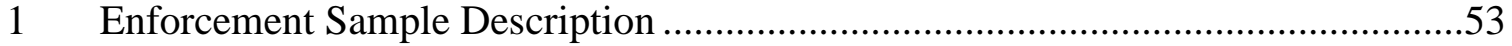

2 Sample Representation by Country .............................................................54

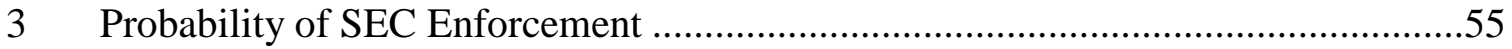

4 Non-Target Foreign Firm Market Returns around Enforcement Announcement

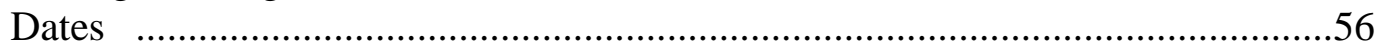

$5 \quad$ Panel Regression Analysis of SEC Enforcement...............................................57 


\section{LIST OF FIGURES}

Figure $\quad$ Page

1 Foreign Enforcement as a Percentage of U.S. Enforcement......................................59

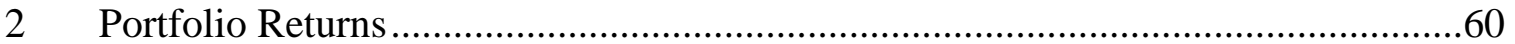

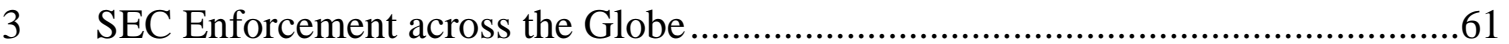




\section{CHAPTER I}

\section{INTRODUCTION}

\section{Challenges Facing Enforcement Research}

The Paulson report (Committee on Capital Markets Interim Report 2006) suggests that the regulatory framework in the U.S. has become overly burdensome to public companies and is responsible for an alleged decline in U.S. market competitiveness. The report cites listing and capital raising choices of foreign firms, who have increasingly bypassed U.S. public markets in favor of private or non-U.S. sources of capital, as evidence of overregulation. Fundamentally, the report questions whether intense regulatory and enforcement processes have "gone too far." On the other hand, the literature emphasizes that enforcement may actuate beneficial components of the regulatory system (Bhattacharaya and Daouk 2002; Coffee 2007; Carvajal and Elliot 2007). Despite repeated calls for more research concerning the capital market effects of enforcement, little empirical evidence exists to guide the controversial academic or public debates. ${ }^{1}$

One reason for this scarcity is that contemporary research faces basic challenges when studying enforcement. Enforcement activity exhibits little variation in most research settings and, where significant variation in enforcement (across countries or over time) does exist, endogeneity concerns are a factor. Most research settings fail to overcome these concerns, and are instead forced to find resourceful methodologies ways to study enforcement. For example, Bhattacharaya and Daouk (2002) exploit the first insider trading prosecution as a shock to enforcement. They show that the cost of equity

\footnotetext{
${ }^{1}$ Leuz (2006), Bhattacharaya (2006), Holthausen (2009), and Daske et al. (2008) explicitly solicit research in this area.
} 
declines in the five years following the first enforcement action. However, the authors note that the ten-year horizon used in the study exposes these findings to a variety of concerns. Broader initiatives that intend to promote market development may be correlated with insider trading enforcement events. While omitted from their model, these initiatives could be responsible for some or all of the capital market effects, thereby confounding their results. Jackson and Roe (2009) use regulators’ scaled staff and budgetary resources as a surrogate for enforcement intensity and show a positive association with market development. However, as the authors point out, strong financial markets may petition governments to protect participants, rendering the observed relation between enforcement and capital markets across countries bidirectional. Even the basic definition and measurement of enforcement can be complicated. For example, La Porta et al. (2006) and Djankov et al. (2005) construct enforcement indices in order to measure regulators' formal authority. Other research, however, suggests that practical levels of enforcement often depart from the legal authority vested in the regulator (Coffee 2007; Jackson and Roe 2009). ${ }^{2}$

\section{Research Setting}

Using a measurable enforcement output (enforcement actions), I reveal a recent surge in SEC enforcement intensity toward foreign firms. After controlling for endogenous factors that impact levels of enforcement (e.g. malfeasant firm behavior and the number of foreign firms listed in U.S. markets), I find that SEC enforcement actions targeting foreign firms are up to 28 times more likely post-2002. The increase in enforcement intensity identified in this study is associated with several factors. First, the

\footnotetext{
${ }^{2}$ Note that these examples illustrate all three types of endogeneity in the context of enforcement research: omitted variable bias, simultaneity, and measurement error (Woolridge 2002).
} 
Sarbanes-Oxley (SOX) act required enhanced disclosure related to internal controls and increased director and officer liability (Berger, et al. 2010). Also, enhanced scrutiny of foreign firms could result from related increases in SEC budget appropriations. Second, enforcement may be a spill-over effect from the post-September $11^{\text {th }}$ information sharing agreements with foreign authorities that facilitate the acquisition of information likely to facilitate litigation. As a matter of national security, these covenants are intended to help identify terrorist financing activity. However, they also have important unintended consequences for enabling the SEC's pursuit of misbehaving foreign firms via enhanced networks of international cooperation. Finally, in 2005 the SEC announced that it would carefully review the reporting outcomes of financial reports under both International Financial Reporting Standards (IFRS) and U.S. GAAP. This announcement was followed by a wave of SEC-prompted restatements.

The increase in enforcement intensity in the context of U.S.-listed foreign firms presents numerous useful opportunities for research. First, from the perspective of a nontarget foreign firm, the surge of enforcement actions represents a series of exogenous shocks to the regulatory environment. I employ these actions as part of a novel eventstudy that investigates the valuation consequences of SEC enforcement on non-target foreign firms. Using short windows surrounding the enforcement events permits stronger inferences about the direction of the relation between enforcement and capital market outcomes. Second, in contrast to studies that evaluate a single regulatory or enforcement event, the multitude of enforcement actions is idiosyncratic, leaving the series less vulnerable to confounding events. ${ }^{3}$ Third, exploiting variation in firms’ home market

\footnotetext{
${ }^{3}$ SEC enforcement actions are announced as they take place, and therefore these shocks to peer (nontarget) firms tend to be distributed randomly throughout time (see Figure 2a and $2 \mathrm{~b}$ for details). Therefore,
} 
legal strength provides cross-sectional predictions that condition the expected effects of enforcement, thereby strengthening the research design and inferences (see Posner 1974; Watts and Zimmerman 1978; Mulherin 2007). Fourth, this setting is ideal for studying pre-existing statutory obligations that are roused to action by enforcement. Finally, U.S.listed foreign firms are at the heart of the debates concerning the value of enforcement and capital market competitiveness of the U.S., making this context ideal for further investigation.

Foreign firms listed in the U.S. represent a significant fraction of global market capitalization, with cross-listed firms alone exceeding $\$ 8$ trillion (Gozzi, et al. 2007). That many foreign firms choose a U.S. listing, is not surprising given prior literature which shows lower financing costs are associated with a U.S. listing. However, viewpoints differ about the mechanisms by which this reduction takes place. Some research proposes that foreign firms choose a U.S. listing because the enhanced legal framework helps protect shareholders and requires high quality disclosure. Known as the "bonding hypothesis," the pledge to meet the demands of the American legal environment implied by a U.S. listing is viewed as a signal regarding a firm's commitment to enhanced disclosure and investor protection. ${ }^{4}$ However, others question the bonding hypothesis on the grounds that SEC and private oversight provided by a U.S. listing are largely mythical. For example, the SEC's enforcement policy towards crosslisted firms has been described as a "free pass” (Shnitser 2010), "rare” (Coffee 2002, p

I see no reason to expect that other information is systematically correlated with foreign enforcement actions.

${ }^{4}$ The "bonding hypothesis" is often attributed to Rene Stulz or John Coffee who, in the spirit of Jensen and Meckling (1976), describes bonding as "the costs or liabilities than an agent or entrepreneur will incur to assure investors that it will perform as promised, thereby enabling it to market its securities at a higher price" (Coffee 2002). 
47; 2007, p 55), and "hands off" (Licht 2003, p 143), while Licht et al. (2011, p 15) state that "the rumors of the SEC's imminent threat of public enforcement have been greatly exaggerated.” In a study of cross-listed Mexican firms, Siegel (2005) finds that SEC enforcement actions against these firms are practically nonexistent and suggests that this trend extends to all foreign firms. ${ }^{5}$ These studies maintain that the cost of capital benefits associated with a U.S. listing are due primarily to overcoming investment barriers, such as formal restrictions on domestic equity ownership or informal restrictions related to transaction costs (Merton 1987; Errunza and Losq 1985). This view, known as the "market segmentation hypothesis,” serves as the main alternative to the bonding hypothesis.

Prior research has wrestled with empirical challenges in testing the bonding hypothesis. ${ }^{6}$ First, because firms self-select into a U.S. listing, finding a comparable benchmark is difficult. Some studies try to overcome this problem by using firms as their own control (e.g., pre-U.S. listing). However, simultaneous changes to fundamentals, such as expected growth, capital structure, and liquidity, obscure the source of any measured valuation benefit of a U.S. listing. These fundamental changes increase the difficulty of attributing valuation effects of cross-listings to the bonding hypothesis, market segmentation hypothesis, or both. While this study does not attempt to capture the ex ante signal of foreign firms entering U.S. markets directly, it contributes to this literature by testing the premise that increased legal oversight affects security value, a key prediction of the bonding hypothesis.

\footnotetext{
${ }^{5}$ Similar evidence is presented by Frost and Kinney (1996) who demonstrate substantially lower disclosure frequency, later annual filings, and an absence of enforcement despite significant noncompliance with U.S. disclosure obligations.

${ }^{6}$ See Karolyi (2010), Hail and Leuz (2009), Leuz (2006) and Benos and Weisbach (2004).
} 


\section{Preview of Results}

I offer two stages of tests that evaluate: (1) the SEC's enforcement intensity regarding foreign firms over time and (2) the enforcement consequences for peer foreign firms not accused of wrongdoing ("non-target” firms). This study, works to establish that the intensity of SEC enforcement has increased. While the frequency of SEC enforcement actions targeting foreign firms has increased prominently after 2002, fluctuations in enforcement frequency over time are jointly determined by the enforcement mechanism and malfeasant firm behavior (Demsetz 1967; Peltzman 1976). ${ }^{7}$ Therefore, research design elements that preclude alternative explanations (such as an escalation in firm-level wrongdoing or the number of U.S.-listed foreign firms) are needed to establish that enforcement mechanisms have changed. To do so, I apply litigation models from prior literature to SEC enforcement actions against foreign firms, integrating an innovative proxy for wrongdoing (using class action litigation) to model the SEC's enforcement choice. Based on Siegel's (2005) results and the environmental changes discussed above (e.g. SOX, SEC budgetary increases, September $11^{\text {th }}$, and IFRS considerations), the analysis is partitioned into two separate time periods: pre- and post2002. I find that after controlling for factors such as the number of foreign firms listed in U.S. markets and accusations of wrongdoing, the probability of foreign firms being targeted by SEC enforcement actions has increased by several orders of magnitude in the post-2002 time period.

\footnotetext{
${ }^{7}$ The increase in the enforcement of foreign firms could also represent a broader increase in SEC enforcement that is relevant for both foreign and domestic firms. Although this source of the increase would not undermine the research design, Figure 1 demonstrates that as a percentage of U.S. enforcement (which has indeed increased over time) the fraction of enforcement actions targeting foreign firms increased sharply after 2002.
} 
This policy shift from passive to aggressive SEC enforcement provides data useful for evaluating the consequences of enforcement. Results indicate that when the SEC pursues a foreign firm, non-target foreign firms' abnormal stock returns are approximately $0.4 \%$ per action (using a 10 -day window). Thus, in this context, active regulatory oversight appears to be associated with increases in firm value. In economic terms, the valuation impact on non-target foreign firms associated with the SEC enforcement actions is considerable. The total increase in the market value of the nontarget firm portfolio is larger than the market value lost by the target firm, indicating an infusion of capital, rather than a redistribution of capital within the foreign investment portfolio. Within the cross-section of foreign firms, I find that the country of origin is associated with the magnitude of the valuation impact in predictable ways. Firms from countries with weaker legal environments exhibit an amplified response to SEC enforcement relative to countries with strong legal environments. Finally, I demonstrate that the magnitude of the response to extraterritorial SEC enforcement declines over time, consistent with the market expectation of SEC oversight gradually adapting to the regime shift. Taken together, these findings conform to the key predictions of the bonding hypothesis, which proposes that foreign firms enjoy significant valuation benefits as a consequence of withstanding increased enforcement and oversight.

The primary results are robust to a battery of sensitivity analyses and alternative research designs. Portfolio-based results are constructed to account for cross-sectional dependence across firms. These results are robust to alternative specifications of abnormal returns, return windows, and outlier treatment. Simulations that randomly assign treatment dates (stratified to match yearly enforcement frequencies) rarely yield 
returns that exceed the actual enforcement dates, indicating that the results are not driven by an omitted risk factor. Results are also consistent using a panel regression framework with daily abnormal returns as the dependent variable. These regressions include controls for size and the market to book ratio, as well as country-, industry-, and yearfixed effects with standard errors double-clustered by firm and date.

This study seeks to contribute to the sparse literature on enforcement, the public discussions regarding U.S. market competitiveness, and to the debate in the academic literature concerning the bonding hypothesis. The research design captures the effects of changes that are confined to the legal environment of foreign firms, thereby providing evidence that circumvents the issues of self-selection and changes to firm fundamentals that accompany a U.S. listing. Quantifying capital market benefits of enforcement has eluded prior research and regulators (Sherwin 2005). This study, however, helps identify value in active enforcement of the capital markets. While some prior literature attempts to measure the costs of regulation (e.g. declines in the number of foreign listings, decreases in capital raised in U.S. markets, delisting choices of foreign firms), the benefits of regulatory enforcement documented in this study indicate that enforcement intensity can be a desirable feature from the perspective of higher quality foreign firms who can withstand intense scrutiny. Finally, to my knowledge, this study is the first to link positive market-wide valuation effects to specific enforcement actions. Such results extend prior research by indicating a causal direction for the previously documented association between public enforcement and market development proposed by Coffee (2007), Jackson (2007), and Jackson and Roe (2009). ${ }^{8}$

\footnotetext{
${ }^{8}$ This however, does not rule out the possibility that elements of the causal structure could be bidirectional.
} 


\section{Chapter Outline}

The dissertation proceeds as follows: Chapter II discusses background literature related to the value of capital market oversight and describes reasons why the SEC enforcement policy toward foreign firms has shifted over the past decade. Chapter III develops hypotheses that relate to the SEC policy toward foreign firms over time, the effect on non-target foreign firms, and cross-sectional and temporal predictions. I discuss sample data in Chapter IV. Chapter V describes the research design and main results. Finally, Chapter VI briefly discusses additional analyses that explore information transfer. Chapter VII concludes. 


\section{CHAPTER II}

\section{BACKGROUND}

\section{Effects of Regulation on Foreign Firms}

An emerging line of research seeks to evaluate the impact of regulatory changes (e.g. SOX, SEC rules, and Supreme Court decisions) on U.S.-listed foreign firms. Piotroski and Srinivasan (2008) study the effect of SOX on the listing decisions of foreign firms, pitting U.S. markets against comparable markets in London. Their evidence shows that SOX has had little impact for large firms considering a U.S. or London Stock exchange listing, but after SOX, smaller firms were more likely to select the Alternative Investment Market (London) rather than U.S. exchanges. Doidge et al. (2010) evaluate the exodus of foreign firms from U.S. markets as a result of SEC Rule 12h-6, which makes it easier for a cross-listed firm to deregister from their U.S. listing (thereby eliminating the requirements of U.S. laws, including SOX). Firms that deregister possess characteristics that indicate greater agency costs, inferior growth opportunities, poor performance, and little need for external financing. Ultimately, they conclude that SOX regulations were probably not a major determinant of the decision to exit U.S. markets. In a related study, Fernandes et al. (2010) document that the option to flee from the rigorous U.S. legal system (provided by SEC Rule 12h-6) is associated with a negative and significant share price reaction for firms from weak home legal environments, while the response is insignificant for firms from strong home legal environments. The evidence from these studies indicates that shareholders may perceive value from U.S. oversight, but that the impact may be determined by firm-specific factors (such as home market legal strength). 
Licht et al. (2011) investigate a Supreme Court decision (Morrison v. Australia National Bank) that obstructs the ability to apply U.S.-style private class action litigation extraterritorially. This change, which denied the protection of U.S. civil liability for investors in foreign located transactions, exhibits a positive association with foreign firm abnormal returns, suggesting that the reduction in potential liability actually enhanced the value of U.S.-listed foreign firms, consistent with the interpretation that the previous civil liability regime was too onerous. ${ }^{9}$ Gagnon and Karolyi (2011) study the same events related to the Supreme Court decision but reach the opposite conclusion. Using a sample that is limited to instances where shares viably trade both in the U.S. and foreign markets, they provide evidence that the U.S.- versus home-market share prices deviate from parity such that U.S. shares trade at greater prices. This result is consistent with the legal system creating fundamentally different classes of shares for which the option to invoke the U.S.-style private right of action possesses measurable value (see Stulz (2009) for further details).

\section{Capital Market Consequences of Enforcement}

While the enforcement construct is absent from these studies, we do learn that foreign firms have experienced several regulatory changes, and many provide outcomes indicating that some features of the U.S. legal environment are valued by investors. Outside of this context, a handful of papers empirically consider the vital role of enforcement activity in obtaining compliance with existing regulations (Coffee 2007; Holthausen 2009). For example, Bhattacharaya and Daouk (2002) use the first time insider trading laws are actually enforced as the proxy for enforcement and conclude that

\footnotetext{
${ }^{9}$ The key dates related to Morrison also map onto key dates related to the Dodd-Frank act, making the net change in the regulatory environment potentially ambiguous.
} 
the establishment of insider trading laws has no discernible impact on a country's cost of capital until those laws are actually enforced. Jackson and Roe (2009) use regulators’ real resources as a surrogate for enforcement intensity and provide evidence that market development is positively associated with public enforcement, even after controlling for the effect of private enforcement. Kedia and Rajgopal (2011) use actual enforcement actions to argue that restatements are less likely when SEC enforcement threat salience is greater (as measured by geographic proximity to the SEC, and past geographic enforcement intensity). Christensen et al. (2011) use a more active research design that examines the effect of two new directives related to insider trading/market manipulation and corporate reporting/disclosure. Their research design exploits the staggered directive implementation and shows that market liquidity increases following the directives, and the improvement in liquidity is more prominent in countries with an existing framework that can apply and enforce the directives more stringently.

\section{Changes in the Enforcement Environment}

In the context of foreign firms in U.S. markets, however, empirical proxies of enforcement intensity often elude prior research, in part because, based on Siegel's (2005) study, enforcement of foreign firms is often assumed to be illusory. ${ }^{10}$ The dramatic expansion of foreign SEC enforcement in the 2000's is associated with several

\footnotetext{
${ }^{10}$ Although lack of enforcement by the SEC and possible failure of private litigation led Siegel to conclude that the U.S. legal environment is of little consequence to foreign firms, other research raises concerns about the methods used in, and conclusions drawn from, Siegel's study (Benos and Weisbach 2004; Doidge 2004; Leuz 2006; Coffee 2007). Leuz (2006) and Coffee (2002) stress that legal bonding does not imply that scrutiny of foreign and U.S. firms be equivalent. The necessary condition for bonding merely requires that entry into U.S. markets provides an incremental improvement in disclosure or minority shareholder protection. Coffee (2002) goes on to point out that SEC oversight can take place in a multitude of ways, including informal and unobservable contact. Furthermore, ad hoc examination of specific SEC actions (or lack thereof) does not constitute an effective test of bonding (Coffee 2002; Benos and Weisbach 2004). Nonetheless, Seigel's (2005) main conclusions about creating reputational assets are not predicated upon an enforcement deficiency.
} 
factors. First, the terrorist attacks of September 11, 2001 increased the priority of crossborder information sharing. In response, the USA Patriot Act of 2001 required remediation of intra-jurisdictional enforcement cooperation at the SEC, Department of Justice, and Financial Crimes Enforcement Network (a division of the U.S. Treasury known as "FinCEN"). The Patriot Act's formal objective is to deter and punish terrorist acts across the globe via enhanced law enforcement and regulatory tools. Numerous sections of the Patriot Act have specific provisions to enable extraterritorial enforcement. For example, section 311 (Special Measures) allows the identification of customers and oversight of payable-through accounts for foreign banking institutions. If jurisdictions or countries are not cooperative or are incapable of providing adequate procedures, they can suffer the imposition of prohibitions against transacting with any members of the U.S. financial system. Sections 313 (Prohibition on U.S. Correspondent Accounts with Foreign Shell Banks), 314 (Cooperative Efforts to Deter Money Laundering), and 319b (Bank Records Related to Anti-Money Laundering Programs) provide explicit power to prevent, investigate, disrupt, and pursue terrorist financing, money laundering, and related illegal activities that take place outside the U.S. territory. ${ }^{11}$ These initiatives paralleled the global efforts of the International Organization of Securities Commissions (IOSCO), Financial Action Task Force (FATF), and Financial Stability Forum (FSF) (Friedman et al. 2002).

\footnotetext{
${ }^{11}$ See http://www.uspatriotact.org/ and http://www.fincen.gov/ststutes_regs/patriot/ for more details.
} 
Those within the SEC, like the acting director of the Office of International Affairs, Felice Friedman, noticed practical differences following the terrorist attacks:

"The effects of the events of $11^{\text {th }}$ September, 2001 on securities markets underscored the importance of international cooperation among regulators. In the aftermath of the attacks securities regulators cooperated - perhaps more than ever before. Regulators were in touch on a daily basis to exchange regulatory and enforcement information, and consulted with one another about the regulatory relief they were considering." -Friedman et al. (2002, p 37)

Both the Department of Justice and the SEC established more formal mechanisms that promoted cross-border cooperation and anti-terrorism intelligence. These mechanisms include Multilateral Legal Assistance Treaties (MLATs) and Multilateral Memorandum of Understanding (MMOU), respectively. The MMOU was brokered by IOSCO and outlines the scope of the international assistance, permissible uses of the information acquired, and explicitly states conditions under which the information will be confidential (Friedman et al. 2003). ${ }^{12}$

Other concurrent factors have also contributed to increased enforcement. For example, the Sarbanes-Oxley Act of 2002 expands various disclosure, internal control, and CEO compensation clawback provisions (Berger, et al. 2010). ${ }^{13}$ In addition, the SEC budget increased by $21 \%$ in 2002 and $40 \%$ in 2003, the largest two increases during the 16-year sample period. Finally, IFRS deliberation prompted the SEC to scrutinize the financial reports of foreign firms as they reconsidered the need for foreign firms to provide reconciliation to U.S. GAAP (see Gordon, et al. (2011) for details). The

\footnotetext{
${ }^{12}$ Importantly, the MMOU does not require that the activities be illegal in both countries (dual criminality), and establishes channels through which the SEC can execute asset freezes (see http://www.sec.gov/news/press/2010/2010-153.htm). The SEC also obtained an exemption from the U.S. Freedom of Information Act (amended, 2002), to ensure that after a foreign regulator surrenders information, its public disclosure is still at the discretion of the original regulator.

${ }^{13}$ As one example of the practical enforcement of SOX for foreign firms, see SEC v. Vivendi Universal, S.A., Jean-Marie Messier, and Guillaume Hannezo, available at http://www.sec.gov/litigation/litreleases/lr18523.htm.
} 
education taking place within the SEC contributes to an enhanced understanding of IFRS and its misapplication. While separating the contribution made by each of these factors (September $11^{\text {th }}$, SOX, budgetary increases at the SEC, and IFRS) to the enforcement intensity of foreign firms is difficult, the expected result is an increase from the ineffective regime documented by Siegel (2005) to a more extensive foreign enforcement policy at the SEC.

Exploring a parallel trend of increasing enforcement in the private sector, Gande and Miller (2011) find both an increasing frequency of class action litigation targeting foreign firms and that target firms bear significant penalties. They predict private litigation using firm fundamentals and aspects of historical return behavior and find limited support for the notion that the probability of litigation is related to the quantity of U.S. sales. Kim and Skinner (2011) also report that the probability of private litigation is unaffected by foreign location of incorporation (see Kim and Skinner (2011), Table 8), but because less than $1 \%$ of their sample is foreign incorporated, reliable inferences about the relative probability of litigation based upon location of incorporation cannot be drawn. ${ }^{14}$

\section{Predicting SEC Enforcement}

Although predicting SEC enforcement is less common in the literature, some papers model SEC financial reporting enforcements (Accounting and Auditing Enforcement Releases-AAERs) as a surrogate for restatements due to irregularities and fraud. Schrand and Zechman (2011) link the probability of receiving SEC AAERs to executive overconfidence. They use multiple proxies for overconfidence based upon

\footnotetext{
${ }^{14}$ These authors simply use the foreign incorporation variable as a control variable and do not attempt to draw conclusions based upon this designation.
} 
executive option exercise, accounting-based measures related to investing and financing activities, dividend policy, and leverage. Dechow et al. (2011) use financial, nonfinancial, off-balance-sheet, and market-based measures to develop a score that predicts the probability of misstatements that are identified by SEC AAERs. My research inquiry is somewhat different in that I seek to evaluate the SEC's choice to pursue firms, whereas Dechow et al. (2011) explicitly seek to predict the existence of misstated financial reports. To my knowledge, no study has attempted to evaluate the choice of the SEC to pursue firms, or its impact. 


\section{CHAPTER III \\ HYPOTHESIS DEVELOPMENT}

Introduction

To investigate the effects of enforcement on capital markets, I first consider the SEC enforcement policy toward foreign firms and then study the market response of their non-target U.S.-listed foreign peers. Finally, I evaluate the cross-sectional association between returns and home country legal characteristics and the magnitude of the market response over time.

\section{Probability of Enforcement}

In the pre-2002 time period examined by Siegel (2005), pursuit of foreign firms was rare, despite compelling evidence of asset taking by Mexican firm insiders. However, the evolution of the environment described in the previous chapter (which motivates enforcement for foreign firms) provides a context that can provide important evidence concerning enforcement, and also explore the potential effects of increased SEC enforcement. For example, in August of 2002, Gary Goodenow, an attorney at the SEC’s Division of Enforcement described the practical level of enforcement cooperation: "The SEC and other regulators...have only very recently begun considering information sharing between financial regulators” (Vaknin 2002). Market awareness can also be demonstrated by PriceWaterhouseCoopers’2003 Securities Litigation Study which observes that "the SEC entered into new cooperation agreements with the European Union and various EU countries’ securities regulators, as many more securities litigation matters went 'global'” (PriceWaterhouseCoopers 2004, p 2). However, because the SEC never provided an official "free pass" to foreign firms, a publicly expressed amendment 
to this policy would be a tacit admission that a "hands-off" policy was applied in the past, which is inconsistent with the SEC's mission. I neither expect nor find an explicit announcement that the policy changed. However, the various environmental changes all point to the potential for a practical increase in the enforcement of foreign firms, which motivates the first hypothesis (stated in alternative form):

H1: The probability of SEC enforcement targeting foreign firms is greater in the post-2002 period, than the pre-2002 period.

\section{Valuation Effects of Enforcement}

Investors perceive value in enforcement for several reasons. First, increased SEC enforcement could represent an increase in public monitoring. If public and private monitoring are substitutes, an increase in public monitoring will reduce the need for, and cost of, private monitoring (Jensen and Meckling 1976). If they are compliments, the marginal value of private monitoring will rise with increases in SEC enforcement. Increased public monitoring could place additional constraints on aberrant activities within foreign firms. For example, Kedia and Rajgopal (2011) demonstrate that the propensity to engage in rogue behavior is inversely related to enforcement threat salience (measured by historical county-level SEC enforcement). Similarly, I expect that in cases of SEC enforcement of foreign firms, other U.S.-listed foreign firms are a relevant peer group for both managers and investors to reassess enforcement intensity. If the SEC is providing scrutiny of foreign firms that would otherwise not be held to such standards, shareholders of the firms may perceives value in such oversight.

Second, the discussion above describes one central theme of the bonding hypothesis, which proposes that the value of a U.S. listing is partly driven by a credible 
signal to uphold higher standards of investor protection and disclosure. Legal bonding requires that the oversight of the SEC and the threat of enforcement be sufficient to reduce investor perceptions of investment risks (e.g. risks decline due to an increased cost of rogue management behavior (Zimring and Hawkins 1973)). A more costly signal, in the form of a greater likelihood of enforcement, strengthens associated valuation consequences provided by a U.S. listing.

Third, enforcement of a foreign firm may convey favorable information about non-target peers. Enforcement against a peer foreign firm could indicate a lower bound for acceptable behavior. Therefore, firms that are not targeted by the SEC may be assumed to exceed this threshold. Similarly, increased security prices could be the result of a redistribution of the capital removed from the target firm (these themes are discussed in detail in Chapter VI: Additional Analyses).

Increased SEC oversight of foreign firms may be related to the various environmental changes taking place over the last decade. However, investors may be skeptical about the practical impact of the MMOU information sharing agreement on extraterritorial enforcement because the SEC has entered into similar information sharing agreements in the commission's history, with little observable impact. For example, Mann and Barry (2005, p 667) state, "Whereas in the past authorities paid polite lip service to cooperation, today it is real.” Indeed, the SEC's Policy Statement on Regulation of International Securities Markets, formally emphasizing the importance of cross-border regulatory networks, had been in place since 1988, but was followed by the weak oversight documented by Siegel (2005). Furthermore, while the International Organization of Securities Commissions (IOSCO) requires an extensive review that 
ensures that MMOU members are capable of fulfilling the terms and conditions therein, the MMOU is not legally binding. The right to refuse to cooperate is at the discretion of the foreign authority.

As a result, the market valuation effects of an enforcement regime shift require evidence of specific actions for the market to resolve uncertainty concerning the actual pace and scope of the more aggressive SEC enforcement policy. Therefore, notification that the SEC has successfully performed this function by pursuing a foreign firm may cause market participants to revise their prior beliefs about the standard to which foreign firms are held. The cost of violating the U.S. rule of law in foreign firms concomitantly increases (and becomes more salient), creating additional deterrents to wrongdoing and reminding the market that foreign firms are not beyond the reach of the SEC (Becker 1968; Jennings, et al. 2011). If investors perceive that the monitoring role of the SEC has expanded, positive returns (higher valuations) to non-target foreign firms may result.

This reason motivates the second hypothesis (stated in alternative form):

H2: Around the dates of SEC enforcements against foreign firms, abnormal returns to non-target foreign firms are positive.

\section{Return Conditioning Effects of Home Country Oversight}

If firms respond positively to increased enforcement oversight, SEC actions should generate larger marginal benefits to firms with the most room for improvement. For example, firms from developing countries with poor investor protection (i.e. weak legal systems, disclosure mandates, and anti-director rights) are likely to experience the 
largest cross-listing benefits (Miller 1999; Doidge, et al. 2004; Doidge 2004). ${ }^{15}$ Also, Doidge, et al. (2007) show that firm-level characteristics have little relation to governance scores in under-developed markets beyond country-level characteristics. This suggests that firms from countries known for poor governance may be unable to change investor sentiments through increasing their governance practices alone and are therefore likely to experience the largest marginal impact from SEC scrutiny. Hail and Leuz (2009) show that the reduction in the implied cost of equity capital provided by cross-listing (after controlling for changes in expected growth) is greater for firms domiciled in weak home regulatory environments. Taken together, these results suggest that if regulatory oversight drives returns around SEC enforcements of foreign firms, firms which are cross-listed in countries with the weakest financial environments will reap the largest benefits. ${ }^{16}$ This reasoning leads to the third hypothesis (in alternative form):

H3: The legal strength of firms' home countries is inversely related to the market value impact of SEC enforcement action for non-target foreign firms.

\section{Intertemporal Return Magnitudes}

The preceding discussion assumes that a change in expectations of SEC enforcement is a contributor to the market's valuation of a firm. Given that extraterritorial capabilities may have only recently become effective, and that this represents a marked change from the prior SEC enforcement policy documented by

\footnotetext{
${ }^{15}$ Under the bonding hypothesis, one major driver of increased value of a U.S. listing is the commitment to higher legal, governance, and investor protection standards, all of which are under the jurisdiction of the SEC.

${ }^{16}$ Christensen et al. (2011) find evidence that countries with stronger existing regulatory frameworks benefit from enforcement directives, while countries with weaker frameworks do not. However, whereas the increased oversight of the SEC in this study is centralized, Christensen et al.'s research context evaluates decentralized directives, questioning the practical change in enforcement for countries with weak prior regulation.
} 
Siegel (2005), one would expect that the initial enforcements in a new enforcement regime would cause the greatest revisions in the market expectations of SEC oversight. Consequently, greater increases in valuation are likely to accrue to the earlier enforcement actions. Therefore, in my fourth hypothesis, I conjecture that the magnitude of the abnormal returns declines over time.

H4: Abnormal returns to non-target foreign firms around SEC announcement dates decline in magnitude over time. 


\section{CHAPTER IV}

\section{SAMPLE}

\section{Enforcement Sample}

Data for the sample are collected from multiple sources pertaining to SEC enforcement actions over 16 years (1995 to 2010). I split the sample into two periods (pre-2002:1995-2001 and post-2002:2002-2010) because the terrorist attacks that prompted information sharing took place at the end of 2001, and because I seek to compare the recent enforcement policy with Siegel (2005) which shows that SEC actions are sparse in the pre-2002 period.

Reported in Table 1, Panel A, the sample of 172 events consists of 28 actions against foreign firms in the pre-2002 period and 144 actions in the post-2002 period, which represents a four-fold increase (4 per year in the pre-2002 period versus 16 per year in the post-2002 period). The nature, time trends, and potential valuation consequences of the enforcement actions vary considerably by type, so I also display four categories of enforcement actions: Insider Trading, Restatement, Foreign Corrupt Practices Act (FCPA), and Miscellaneous.

The Securities and Exchange Commission annual reports provide a description of insider trading enforcement actions. Panel A describes the sample of 52 total insider trading enforcement actions brought against firms and their insiders. ${ }^{17}$ The frequency of foreign enforcements in Panel A increases from 16 actions from 1995-2001 to 36 actions from 2002-2010. I gather restatement data from the SEC website, EDGAR, Audit Analytics, and the GAO database from 1995 to 2010 on all publicly announced SEC-

\footnotetext{
${ }^{17}$ Analyses by firm (rather than by enforcement action) which removes firms with multiple offenses buttress the notion that enforcement actions against foreign firms are far from rare, and ensure that results are not driven by multiple litigation releases for the same firm. These results are unreported.
} 
prompted restatements and financial reporting infractions. I do not include restatements due to mergers, acquisitions, stock splits, or other sanctioned business reporting that arise from unusual, but legitimate, operations (Hennes et al. 2008). The resulting sample consists of 75 restatements, of which 70 are in the post-2002 period. ${ }^{18}$ This represents an increase of over tenfold on a per year basis. Next, are the actions related to the FCPA, which intends to promote competition by prohibiting bribery of foreign officials to obtain an improper business advantage. The FCPA also stipulates certain accounting practices for firms listed in the U.S. Specifically, firms must (a) keep records that accurately reflect the transactions of the corporation and (b) devise and maintain an adequate system of internal accounting controls. The actions demonstrate a meteoric rise in recent years, thanks in part to the International Anti-Bribery and Fair Competition Act of 1998 which expanded the scope of the FCPA. No actions occur prior to 2002, and 20 actions took place after 2002. Finally, Table 1, Panel A shows additional 25 SEC enforcements actions that are not readily classified. These miscellaneous infractions include tax evasion, aiding and abetting other firms committing fraud, and false disclosures (unrelated to financial statements). Many of these events also involve significant fines (which average over 80 million dollars). ${ }^{19}$

Panel B of Table 1 reports the enforcement actions by listing type. Exchange listings represent firms listed on the NYSE, AMEX, or NASDAQ, while OTC represents the over-the-counter markets. ${ }^{20}$ The "Miscellaneous" category includes firms that are

\footnotetext{
${ }^{18}$ Of the 75 actions considered, there are 10 AAERs, 33 Litigation Releases, and 32 restatements from EDGAR.

${ }^{19}$ See, for example, http://www.sec.gov/litigation/litreleases/2006/lr19716.htm.

${ }^{20}$ Hereafter, "listed" securities represent those trading on a major U.S. exchange (e.g. NYSE, AMEX, or NASDAQ). These firms correspond to Level II and III American Depositary Receipts (“ADRs”). In contrast, "unlisted” refers to the OTC markets, which includes Level I and rule 144A cross-listings.
} 
144a private placements, firms that are linked to U.S. markets only through parent or subsidiary companies, or firms that were not listed in U.S. markets at the time the alleged offenses occurred. The overwhelming majority of enforcement actions target listed firms (151 of 172 or $88 \%$ ). This lack of enforcement intensity for unlisted (Level I) firms may contribute to the attenuated cost of capital benefits documented by prior literature for unlisted programs (e.g. Hail and Leuz 2009).

\section{Universe of Foreign SEC-regulated Firms}

To facilitate a better understanding of the frequencies presented in Table 1 Panels A and B, I also collect data to describe the representation of foreign firms listed in U.S. markets by listing type. ${ }^{21}$ As a benchmark, the bottom of Table 1 Panel C provides the fraction of foreign firms in the relevant U.S. market (the 17.8\% represents 2,000 foreign firms in U.S. markets as a percentage of roughly 11,000 total SEC regulated firms). The enforcement proportions reported in Table 1, Panel C do not support the view that the SEC abdicates its responsibility for foreign firms. Enforcement against listed foreign firms as a percentage of total enforcement is generally comparable to the foreign representation in listed markets. For listed securities, the foreign insider trading enforcement actions by the SEC (14.62\%) exceed the underlying representation of foreign firms in the market (10.70\%).

The only major deficiencies apparent in enforcement activity are found in the OTC market. Consistent with prior literature and the reduced regulatory and disclosure requirements for such listing types, the information demonstrates that listing type does

\footnotetext{
${ }^{21}$ Data are obtained via the Bank of New York, OTC Bulletin Board, NASDAQ, and NYSE/AMEX websites and is cross-validated by information from the SEC website. Because the miscellaneous infractions are not clearly classified into a category, I do not report comparable domestic SEC actions.
} 
matter. For example, foreign firms represent $28.70 \%$ of the number of OTC firms, while the fraction of enforcement devoted to them is less than $2 \%$ in each enforcement type. The OTC under-representation of foreign firms in SEC enforcement actions is not surprising given prior research, which shows that for unlisted firms whose SEC requirements are limited the SEC's radar for illegal actions is attenuated (Miller 1999; Coffee 2002; Lang et al. 2003a; Doidge et al. 2004, 2008; Hail and Leuz 2009).

Although these results are similar to Shnitser (2010), she concludes that the SEC pursuit of cross-listed firms is vastly inferior to that of domestic firms. Her analysis, however, does not separately evaluate exchange listed firms and non-exchange-listed firms. Given the empirical support for the SEC's disciplinary role in regulating foreign firms, the SEC's role in regulating foreign firms shall no longer be dismissed as inactive, laissezfaire, inconsequential, or nonexistent. ${ }^{22}$ Figure 1 displays the percentage of SEC enforcement that targets foreign firms by year. The increasing trend of foreign enforcement after 2002 cannot be explained by a broader domestic increase in SEC enforcement activity. ${ }^{23}$

\section{Non-Target Sample}

The sample of non-target firms comes from the intersection of Compustat and CRSP databases. The non-target sample and SEC enforcement actions are reported by country in Table 2. The non-target sample includes 12,502 firm-years from 59 countries.

\footnotetext{
${ }^{22}$ The information in Table 1 should be interpreted cautiously in assessing SEC enforcement equality. The groups may have differences in the underlying frequency or severity of misconduct and the home country may share a portion of the regulatory burdens with the SEC, which could distort observed frequencies. For example, in multiple instances the SEC deferred its prosecutorial role to home regulators because of "double jeopardy" concerns that would interfere with home market investigations (see, for example, Friedman et al. 2002).

${ }^{23}$ I hasten to point out that even if this were the case, the conceptual strengths of the study would remain intact.
} 
Roughly $43 \%$ of the sample is from Canada, Israel, or the United Kingdom. The percentage of firm-years that are subject to an SEC enforcement action are also reported by country, and presented in a geographic format in Figure 3. The intensity of the color in Figure 3 is proportional to the percentage of firm-years that are subject to SEC enforcement, and indicates that the reach of SEC enforcement does indeed span the globe. 


\section{CHAPTER V}

\section{RESEARCH DESIGN AND EMPIRICAL RESULTS}

The hypothesis tests are presented in the following three sections. First, I examine the SEC's choice to pursue foreign firms (H1). Next, I turn to non-target foreign firms. I examine the magnitude and timing of the market response using a portfolio-based event study framework (H2). I then take account of the fact that several of the portfolios overlap and control for other factors that could affect returns by using an alternative pooled time-series cross-sectional regression framework. This approach also allows me to assess the home country characteristics that condition the market response at the firm level (H3) and the return magnitude over time (H4) using panel regression.

\section{Probability of SEC Enforcement}

To the best of my knowledge, this is the first study to model the SEC's enforcement intensity of foreign firms. As discussed in the previous chapter, the frequency of SEC enforcement has dramatically increased. However, the fundamental issue is whether the SEC enforcement intensity has changed. While suggestive, the enforcement frequency tabulated in Table 1 may not furnish such evidence. I emphasize a difference in enforcement intensity versus enforcement frequency, which is that increased frequency may be due to an increasing number of malfeasant events within foreign firms, rather than an increased intent to prosecute on the part of the SEC (i.e. intensity). For example, differences in SEC enforcement frequency of foreign firms across time could be an artifact of an increase in the number of foreign firms in U.S. markets or increased wrongdoing by foreign firms. Indeed, Gande and Miller (2011) describe an upward trend in private litigation targeting foreign firms in U.S. markets. I 
estimate model (1), shown below, using logistic regression with the dependent variable set equal to ' 1 ' in the year of SEC enforcement (' 0 ' otherwise).

$$
\begin{aligned}
& S E C \_A C T I O N_{i t}=\alpha_{0}+\alpha_{1} \text { POST }+\alpha_{2} \text { CLASS_ACTION } i t+\alpha_{3} M B_{i t-1}+\alpha_{4} \text { SIZE }_{i t-1}+\alpha_{5} \text { RETURN }_{i t-1}+ \\
& \alpha_{6} \text { SKEW }_{i-1}+\alpha_{7} \text { TURNOVER } R_{i-1}+\varepsilon_{\text {eit }}
\end{aligned}
$$

Model (1) includes a set of control variables used in prior research including size, market-to-book ratio, and prior year market-adjusted returns, cumulative turnover, and return skewness (see Appendix A for details). By necessity, the model is more limited than the set of controls used by Dechow et al. (2011) in order to preserve the maximum number of observations for subsequent analyses. ${ }^{24}$ To rule out increasing patterns of malfeasant behavior as an explanation for the increase in enforcement, I also include class action litigation as a proxy for wrongdoing, using an indicator variable equal to ' 1 ' when a firm has been named as a defendant in a class-action lawsuit in the previous 5 years. ${ }^{25}$ The regression implicitly controls for variation in the number of foreign firms over time.

The results, which use estimates of standard errors by clustering at the firm level, are presented in Table 3. Panel A displays the results for separate regressions in the pre2002 and post-2002 time periods, as well as the entire sample period. The coefficient on $\alpha_{1}$, the indicator for the post-2002 time period ('POST'), is positive and significant with an odds ratio estimate of 4.25. This suggests that, after controlling for allegations of wrongdoing, the number of foreign firms in U.S. markets, and the other firm-level variables, the SEC enforcement intensity in contemporary time periods has increased

\footnotetext{
${ }^{24}$ In untabulated results, the main variables of interest are largely unaffected by incorporating the broader set of controls identified by Dechow et al. (2011).

${ }^{25}$ I choose 5 years because the statute of limitations for the SEC is typically 5 years. See Section 3.1.2 of the SEC 2011 enforcement manual, available at www.sec.gov/divisions/enforce/enforcementmanual.pdf.
} 
425\%. I also compare the SEC enforcement policy across the two time periods. The Chi-squared joint test of parameter equivalence across the two periods is rejected ( $\mathrm{p}=.03$ ), indicating that the SEC enforcement policy has changed. These findings are consistent with the notion that the events described in Chapter II had a significant effect on the SEC enforcement intensity (H1). Panel B estimates the model separately for each enforcement action type. Results indicate that insider trading enforcement intensity has not increased over time, but restatement, FCPA, and miscellaneous enforcement actions increased by a factor of more than 28,12 , and 7 , respectively. To summarize, these results are consistent with H1.

\section{Portfolio Abnormal Return Analysis}

The increased enforcement intensity shown above may benefit non-target foreign firms' investors because SEC scrutiny reduces the cost of external monitoring and increases the cost of insider malfeasance. Muradoglu and Huskey (2008) and Salavei et al. (2009) examine the market response of target firms to SEC enforcement actions and find that such firms experience significant negative abnormal returns associated with the SEC announcements. These returns to target firms begin around day -1 and change little after day +8 relative to the announcement date. Accordingly, I choose to examine 10-day $(-1,+8)$ returns to a portfolio of non-target foreign firms on U.S. stock exchanges as the event period return window. I also report the anticipatory period $(-14,-2)$ and the subsequent period $(9,16)$ returns. Although the results are equivalent using a variety of abnormal return specifications, I report market-adjusted abnormal returns to ensure the 
broadest sample possible. ${ }^{26}$ Similar to Leuz, Triantis, and Wang (2008), the marketadjusted abnormal return deducts the CRSP value-weighted index from each firm's raw return.

I identify cross-listed firms via depositary bank websites (JP Morgan, Citigroup, and the Bank of New York’s ADR.com), ADR and ADS firm name headings from Compustat and CRSP, and the SEC website. I identify other foreign firms using the location of their incorporation in Compustat. I require that firms have return data for each of the 10 days within the event period window $(-1,+8)$. I use the universe of foreign and cross-listed firms covered by CRSP to form equally-weighted portfolios at each SEC action date because well over 100,000 observations (firm-events) are available in CRSP. ${ }^{27}$ This approach mitigates potential cross-sectional dependencies that could bias the standard error estimates (Sefcik and Thompson 1986). The 171 portfolios constructed for each unique SEC enforcement action date assume that different events are uncorrelated, which is not unreasonable given the random nature of the enforcement event announcement dates. ${ }^{28}$. Standard errors are estimated using an approach similar to Fama and MacBeth (1973).

The specification of abnormal returns presumes that foreign firms do not have omitted risk characteristics that impart a bias upon returns. In order to give closer inspection to this potential confound, I follow Armstrong, et al. (2010) by comparing

\footnotetext{
${ }^{26}$ The alternative specifications tested are raw, market-model adjusted, size-adjusted, and Fama-French three-factor. Results using $(0,4),(-2,+2)$, and $(-1,5)$ event windows are statistically significant with the same sign and comparable (daily return) magnitudes as the ones reported.

${ }^{27}$ I remove any firms who have daily returns (event period CARs) greater than $10 \%(40 \%)$ in absolute magnitude as these represent extreme performance that is likely driven by other firm-specific factors. The average number of firms per event with the necessary information to calculate abnormal returns is about 781. On average, $48 \%$ of the portfolio is comprised of American Depositary Receipt firms.

${ }^{28}$ From the perspective of non-target firms, the enforcement announcement dates temporally random (see Figure 2a and Figure 2b)
} 
event period returns to dates assigned at random. I calculate the $(-1,+8) 10$-day

abnormal returns to the foreign firm portfolio for each trading day from 1995 to 2010.

Dates are selected such that they correspond to the number of observations from each year (stratified by year), and the procedure is repeated 1,000 times. The p-value is the number of times out of 1,000 that the simulated returns exceed the returns around the true event dates. If the abnormal returns in randomly assigned (non-event) periods rarely exceed those in event periods, I have additional confidence that the returns are well specified. This simulation approach also has the advantage of requiring no assumptions about the distributional properties of the abnormal portfolio returns. The simulation results, reported as "simulated p-values” in the far right-hand column of Table 4, support the market-adjusted specification of returns used in the primary tests.

Figure 2a displays the 171 portfolio returns to enforcement announcements over time by type of enforcement. The number of SEC actions targeting foreign firms is an increasing function of time. Panel A of Table 4, which reports the anticipatory, event, and subsequent period returns (in basis points) is consistent with the view that the enforcement announcement positively affects foreign firm security returns. The anticipatory (day -14 to -2$)$ and subsequent period $(9,20)$ returns are insignificant while the event period $(-1,+8)$ returns are positive and significant, consistent with H2. Foreign firms appear to benefit from the SEC action by 41.1 basis points over the 10 -day window. ${ }^{29}$ The Bank of New York estimates that in 2008 the NYSE and NASDAQ held

\footnotetext{
${ }^{29}$ This evidence is descriptive in nature, and the estimates of abnormal return magnitude should be interpreted with caution. For example, several of the 171 observations partially or fully overlap, unduly weighting such time periods, and violating the assumption of independence. Furthermore, 29 SEC enforcement actions in the sample relate to SEC allegations about the same firm. Such actions are usually an extension of existing charges stemming from ongoing investigations (which are unlikely to come as a revelation to the market). Also, despite the affirmation of the simulation results and robustness of the results to a variety of measurements, the literature has demonstrated that other cross-sectional factors such
} 
1.2 trillion dollars of market capitalization for cross-listed firms (BNY 2009), making 4.1 basis points an economically significant daily increase in dollar value.

Panel C of Table 4 partitions firms by the type of violation (insider trading, restatement, FCPA, and miscellaneous). The abnormal returns in each partition are again tested at the portfolio level and the abnormal return estimates for all three types are positive in the 2002-2010 partition. The lack of statistical significance in the pre-2002 period is likely due to a lack of power and sensitivity to extreme observations afforded by the portfolio design (which provides as few as 5 observations in the restatement partition). The full sample shows statistical significance for the Restatements, FCPA, and Miscellaneous categories, but also reveals considerable variation in return magnitude by enforcement type.

\section{$\underline{\text { Panel Regression Analyses of Firm-specific Abnormal Returns }}$}

Given the significant response at the portfolio level reported in Table 4, an exploration of the time-, event-, and firm-specific characteristics that influence the magnitude of the market response to SEC enforcement actions is informative. Therefore, I apply a pooled time-series cross-sectional panel approach that regresses firm-specific daily returns on market controls (such as size and book-to-market ratio) and uses indicator variables to capture the effect of the enforcement actions.

The panel approach, which uses the entire series of daily return data from 1995 to 2010, has several advantages. First, rather than discarding partially overlapping enforcement events, I can capture the effect of enforcement with greater precision by

as book to market ratio and size exhibit significant and predictable relationships with returns (Fama and French 1992; Fama and French 1993; Ferson and Harvey 1999). I address these concerns in the following section. 
using indicator variables to denote proximity to an event. In cases where events overlap, the event information for the most recent event overwrites the old event, such that no event days are double counted. Second, the indicator variables can be interacted with various event-specific data that I expect to be associated with market sentiment, visibility, and consequently returns. Third, the panel accommodates the inclusion of a set of controls for country, industry, and year, as well as measures of market-to-book and size. Finally, the panel facilitates essential statistical tests because I can control for dependencies across time and across firms using modern clustering techniques (Cameron et al. 2006; Petersen 2009; Gow et al. 2010). Also, I avoid assumptions about the return behavior in periods that are not within the SEC enforcement action window because I use the entire series of actual returns in the sample period. In comparison to traditional event studies, the panel structure works against finding a statistically significant result because this approach cannot reduce the variability in daily returns through aggregation. However, to the extent that I find significant results in spite of this bias, I present a conservative statistical estimate of the effect.

Shown below, Model (2) uses market-adjusted abnormal returns for firm ' $i$ ' at time ' $t$ ' (in basis points) for ease of exposition as the dependent variable. The variable definitions are provided in Appendix A.

$$
\begin{aligned}
A R B P_{i t}= & \beta_{0}+\beta_{1} E V E N T_{e}+\beta_{2} E V E N T^{*} R U L E \_L A W \_R A N K_{e}+\beta_{3} C H R O N_{e}+\beta_{4} \\
& R U L E \_L A W \_R A N K_{e}++\sum_{k=1}^{K} \beta_{k} C O N T R O L S+\varepsilon_{e i t}
\end{aligned}
$$

Several variants of model (2) are presented in Table 5 with standard errors double-clustered by date and firm. Each specification also includes controls for industry, year, country, size and market-to-book (all are unreported). First, I test for the effect of 
SEC enforcement actions on returns using a dummy variable, EVENT, set equal to "1" during the $(-1,+8)$ window surrounding an SEC announcement of enforcement targeting foreign firms ("0" otherwise). ${ }^{30}$ Regression (1) includes only the event dummy and controls (market-to-book, size, and country, industry, and year fixed effects). The significantly positive coefficient indicates that the average effect is 4.10 basis points on a daily basis. Nine-hundred fifty-seven unique days fall within the 10-day window, suggesting that the amount of overlap among observations was substantial. Over the sixteen year period, the average annual increase in market value occurring within the windows surrounding the SEC enforcement actions is approximately $2.6 \%$.

\section{Panel Regression Analyses of Home Country Strength on Event Return Magnitude}

Country specific factors may contribute to the market value implications of SEC enforcement actions. H3 posits that returns for foreign firms are conditioned by their home legal environments such that greater returns accrue to firms with weak home country origins. I measure home country legal strength using the Kaufmann et al. (2010) rule of law index. This index, which assesses strength of governmental rule of law, is intended to capture the construction and implementation of regulations that facilitate development of the private sector. I choose this index because it covers the majority of my sample (LaPorta et al. (2006) and Jackson and Roe (2009) provide measures for less than 50 countries versus 212 for the Kaufmann et al. (2010) study) and allows for timevarying changes to the index scores. ${ }^{31}$ To facilitate ease of interpretation, I select the $R U L E \_L A W \_R A N K$ variable that represents the percentile rank of each country, with

\footnotetext{
${ }^{30}$ The results reported in Table 4 exclude the "repeat" observations that relate to extensions of ongoing investigations. Untabulated results indicate that these events produce insignificantly positive results at the portfolio level, and results are equivalent when they are included in the panel.

${ }^{31}$ I interpolate for years 1995, 1997, 1999, 2001, and 2010 by using the mean of the adjacent years.
} 
higher values indicating greater strength. The average of the RULE_LAW_RANK variable over the sample period is reported in Table 2 .

The specification includes $R U L E \_L A W \_R A N K$ and its interaction with the event dummy, EVENT_RULE_LAW_RANK, to capture the effect of home country strength in non-event and event periods respectively. This prevents confusing a trend that exists even in non-event periods with the one I expect will be manifest during the event period (that is, confusing main effects and interaction effects). Also, I include dummies for each individual enforcement event to purge event specific variance in return magnitudes.

The second column presents this specification as a test of the effect of home country legal strength on return magnitude (H3). The negative and significant coefficient on $E V E N T \_R U L E \_L A W \_R A N K$ indicates that firms from weaker home institutions exhibit a greater marginal benefit from SEC oversight, which is consistent with H3. The interpretation of the coefficient is that for a $1 \%(10 \%, 100 \%)$ increase in the percentile rank of home legal strength, the abnormal returns to SEC enforcement actions are lower by $.08(.8,8)$ basis points per day. Results are similar using a common law origin indicator variable to capture home country strength.

Overall, the negative relation between home country legal strength and abnormal returns shown in Table 5 suggests that the firms from weak home legal environments experience the greatest marginal benefit from increased SEC oversight, lending support to H3, the legal bonding hypothesis, and the interpretation that enforcement can add value to firms. This is consistent with Miller (1999), Doidge, et al. (2004), and Doidge (2004) who show that home country characteristics similarly condition the benefits demonstrated at the time of the listing event. My results extend and support their 
conclusions by isolating the effects of increased SEC scrutiny from other features that are associated with the listing event (selection problems and simultaneous changes in liquidity, market segmentation, etc.).

\section{Intertemporal Effect of Enforcement Events on Return Magnitude}

Consistent with legal bonding, the results reported in Tables 3 and 4 indicate that SEC enforcement actions increase the security values of non-target foreign firms and that such returns are greatest in firms from weak home legal environments. These results are consistent with a revised expectation of SEC enforcement intensity being a contributor to the market's valuation of a firm. H4 predicts that the initial enforcements in the new enforcement regime cause the greatest revisions in market expectations and consequently the greatest changes in valuation. Therefore, I test for the decline in the magnitude of the response to SEC enforcement actions over time as the market becomes aware of a more active enforcement program. I use a variable, $C H R O N$, that captures the date of the enforcement action (measured in days past the year 1960), and expect a negative coefficient. The third regression in Table 5 presents the results of this specification, which again includes indicator variables to account for variation in return magnitude by event type. The negative and significant coefficient on $C H R O N$ is consistent with $\mathrm{H} 4$ and provides support for the notion that the revision to the market expectation is greater for earlier rather than later enforcement actions. ${ }^{32}$

\footnotetext{
${ }^{32}$ Regression (4) in Table 5 reports the results of including both the cross-sectional and temporal variables from $\mathrm{H} 3$ and $\mathrm{H} 4$. The results are unchanged.
} 


\section{CHAPTER VI}

\section{ADDITIONAL ANALYSES}

\section{Confounds Affecting the Intertemporal Relation between Enforcement Events and Return Magnitude}

The results in Table 5 indicate that the magnitude of non-target firm returns declines with each sequential SEC enforcement action, consistent with the market impounding greater revisions of expected SEC enforcement for earliest enforcement actions in the changing enforcement policy. However, one factor that could potentially confound the results of this test is the known dynamic nature of capitalization rates over time. For example, even if the information contained in successive enforcement announcements was held constant, the market could capitalize that information differently based upon time-varying context-specific factors (e.g. interest rates, inflation, aggregate risk preferences, perceptions of volatility, etc.). The vast differences in capitalization rates across time could create the illusion of a declining return magnitude that is consistent with $\mathrm{H} 4$, when they are, in fact, not related to declining revisions to the market expectation of enforcement.

To mitigate the effects of changing capitalization rates, I first calculate earnings response coefficients (ERCs). Because ERCs estimate the capitalization factor applied to a dollar of unexpected earnings, they serve as an ideal control for changing capitalization rates. I selected a short-window earnings response coefficient (estimated annually) for foreign firms during my sample period (see Appendix B for details). I then include a three-way interaction term between EVENT, CHRON, and CAP (the annual regression estimate of the ERC) into the regression. The three-way interaction term is included in 
regression (5) of Table 5. The significance of the EVENT*CHRON interaction coefficient drops slightly below conventional levels of significance $(p=.109)$ with the inclusion of controls for changing capitalization rates. While the results remain directionally consistent with idea that revisions to the market expectation of enforcement are greater for earlier enforcement actions, I emphasize that the results are appreciably weaker and only marginally supportive with the inclusion of capitalization rate controls.

\section{Alternatives to Increased Oversight}

The results presented in this study suggest that when a foreign firm is targeted, non-target foreign security prices respond positively. The fact that return magnitudes are inversely conditioned by home market legal strength, and that the market capital decline in the target firm is not large enough to account for the increase in the value of the nontarget portfolio, are consistent with results being driven by additional SEC oversight. However, one alternative mechanism that may explain this result is that enforcement of a foreign firm may convey favorable information about non-target peers because it indicates a behavior threshold below which the SEC will not tolerate. Investors may infer that firms not targeted by the SEC meet this minimum threshold and therefore exhibit less malfeasant behavior than the target firm.

If SEC enforcement actions benefit non-target firms because it is perceived as an indicator of a lower bound of acceptable behavior, then greater returns to enforcement actions should be concentrated within firms bearing the greatest enforcement-related risk characteristics. Therefore, the securities of firms with the greatest probability of enforcement may reap additional valuation benefits related to enforcement actions. I 
hasten to point out that this result is also consistent with at least two other interpretations. First, investors may perceive that the threat of enforcement for a high enforcement-risk firm may be reduced after the SEC reveals a preference for pursuing a different firm. Second, for firms at the margin of acceptable behavior, SEC enforcement of a different firm could indicate political capital at the firm that is ultimately value-enhancing. Furthermore, note that this result would also be predicted under the interpretation of increased oversight, as the greatest effects would be found where the increased scrutiny is greatest.

To explore these alternative interpretations, I use the predicted probability of SEC enforcement from the logistic regression in Model (1) as a covariate in the panel regression event study. I employ two measures of the probability of SEC enforcement. The first, $P H A T$, is the predicted probability of enforcement. The second, HI_PROB, is an indicator equal to ' 1 ' when a firm falls into the highest quintile of predicted enforcement probability. The regressions include the interaction of the probability variables (EVENT*PHAT and EVENT*HI_PROB), in addition to the main effect variables to avoid confusing an event-related trend with a more general cross-sectional trend. Regression (6) in Table 5 reports the results of including the probability of enforcement (PHAT) and its interaction with the event period indicator. While the probability of enforcement, PHAT, is negative, the probability of enforcement does not condition event period returns (that is, EVENT*PHAT is insignificant). However, firm size and book-to-market ratio are two potentially confounding omitted variables during the event period. ${ }^{33}$ Therefore, I repeat the estimation with the inclusion of SIZE and BM

\footnotetext{
${ }^{33}$ SIZE and BM are included as controls in each of the regressions in Table 5, but not as interaction terms with the event period indicator.
} 
variables interacted with the event period, in case these variables play a role in conditioning the event period returns. Regression (7) is consistent with the view that event period returns are positively related to the probability of receiving an enforcement action.

Finally, to explore the possibility that the positive reaction is confined to firms near the threshold of expected SEC enforcement, I include an indicator for firms in the highest quintile of enforcement probability. Results from the eighth regression indicate that firms in the highest quintile of enforcement have a daily return during the event window that is significantly greater by 2.92 basis points $(p<.01)$. Note that the other cross-sectional relationships related to home market legal strength do remain intact. Untabulated results that exclude firms in the highest quintile of enforcement probability continue to indicate significantly positive returns during the event window with an estimated magnitude of 3.86 daily basis points.

Regardless of the interpretation, the fact that (a) none of the specifications subsume the return conditioning effects of home market legal strength, (b) larger firms (with potentially more sophisticated governance and oversight mechanisms) are inversely associated with returns, and (c) the results are reproducible when firms with the highest probability of enforcement are excluded is consistent with regulatory oversight playing a positive role in determining asset prices in the context of U.S-listed foreign firms. Nonetheless, the alternative mechanisms may also play a role in explaining the market response in addition to the increased SEC oversight. 


\section{Response Dynamics: Contagion/Competitive Effects}

The positive valuation effects documented in the previous chapter are compelling given the possibility that increased SEC enforcement actions could trigger losses of credibility to foreign firms, their insiders, and overall financial disclosures. For example, skepticism of earnings is illustrated by Gleason, et al. (2008) in a study of intra-industry information transfer that is consistent with "contagion” effects, which represent a negative spill-over effect for peer firms. In contrast to contagion, “competitive effects” refers to the beneficial reaction of peer firms. Lang and Stulz (1992) show how bankruptcy filings can convey information about demand shifts within an industry. Presumably, competitive effects represent a zero sum game (i.e. over-all industry size is unaffected, while constituents jockey for market share). Interestingly, the aggregate magnitude of the response to SEC enforcement actions renders competitive effects (demonstrated by an investor preference shifting away from the target firm and redistributing capital within the group of foreign non-target peers) unlikely to fully explain these results.

While I demonstrate a net positive aggregate effect of SEC enforcement on the broad peer group of non-target firms, the directional effect of sharing additional characteristics with target firms on return magnitude is yet unknown. On the one hand, more similar peers may indicate more focused scrutiny, and therefore increase peer firms' value. On the other hand, despite the overall positive reaction to SEC enforcements, peer firms' returns could be attenuated or even negatively affected by enforcement if a firm is not in a position to withstand additional scrutiny. For instance, the SEC action could 
identify a country-, industry-, or exchange-wide questionable practice that could increase the expected costs of litigation, documentation, and compliance. Therefore, I am unable to develop directional expectations.

In order to address the possibility of contagion and/or competitive effects, regression (9) in Table 5 includes dummy variables equal to ' 1 ' when the target firm (firm ' $x$ ') and non-target firm (firm ' $i$ ') share the same home country, GICs industry, or

stock exchange. Results indicate that each similar dimension significantly conditions the event-window return magnitude. Firms from the same country experience an additional 6.57 (daily) basis point return. The exchange effects are also positive, but smaller in magnitude (4.74 basis points). Whether this represents competitive effects or is due to enforcement intensity more broadly defined is not known with certainty. Nonetheless, these factors positively condition the return magnitude. Finally, the effect of sharing a common GICs industry is negative (-11.65 basis points). This finding is consistent with contagion and investors responding to SEC enforcement actions with increased skepticism of foreign firms that share industry designation.

\section{An Enforcement Based Trading Strategy}

Although the returns associated with enforcement actions are significant and robust to several specifications, the feasibility of an actual trading rule based upon SEC enforcement remains unknown. In order to explore the returns to an SEC enforcement based strategy, I form equally-weighted portfolios of non-target foreign firms and calculate buy-and-hold returns starting on the day following the enforcement release to 
form a $(+1,+8)$ window. ${ }^{34}$ If events overlap, I continue to hold the investment portfolio until eight days after the most recent enforcement action. This produces 113 distinct investment time periods (due to overlapping periods). After deducting the return to a CRSP value-weighted portfolio during the corresponding time period, the buy-and-hold abnormal returns are on average 64.7 basis points $(t=3.74$, calculated at the portfolio level). Using raw returns, the average return is 54.2 basis points $(\mathrm{t}=2.91)$. These results reveal that a considerable portion of the abnormal return associated with enforcement actions takes place after the information is publicly available. Whether the returns from this strategy would remain viable after taxes and the costs of executing a large number of transactions remains an open question. ${ }^{35}$

\section{Other Robustness Checks}

The sensitivity of the results is described in this section. The regressions reported in Table 5 applied a deletion rule of $\pm 1,000$ basis point $( \pm 10 \%$ ) for the dependent variable ARBP in Table 5 because returns of this magnitude are almost surely due to major firmspecific events, not enforcement. However, to evaluate the sensitivity of my results to alternative rules for the treatment of extreme observations, I apply the following alternative rules: (1) trimmed at the top and bottom 1\%, (2) winsorized at the top and bottom 1\%, and (3) making no adjustments to the distribution. The results are qualitatively unchanged. Also, in Table 5, only the first enforcement events are included in cases where a firm is subject to multiple enforcement actions because these ongoing

\footnotetext{
${ }^{34}$ I do not truncate or winsorize any returns, as these would be unknown ex ante in an investment strategy.

${ }^{35}$ A simplified strategy of investing in the BLDRS ADR Index avoids the need to execute hundreds of transactions, thereby reducing the cost of the trading rule. However, this does not yield statistically significant returns, so the practical viability of such a trading rule remains questionable.
} 
enforcement proceedings are not likely to represent a revelation to the market.

Unreported results that include all dates yield event returns which are slightly smaller in magnitude, but remain statistically significant.

Another concern is that the U.S. market for some dual-listed shares can be illiquid, thereby creating measurement error. Results are unaffected by removing illiquid shares (defined as those shares that are in the bottom quintile of the share turnover distribution during the previous quarter). Finally, after I exclude the largest countries (Canada, Israel, and the United Kingdom) to ensure that the results are not being driven by certain countries, I find that results excluding these countries are even more favorable to the hypothesized relationships.

\section{Cost of Regulation}

This study finds evidence of benefits associated with capital market enforcement activities. On the other hand, regulation is not without costs. To provide an estimate for the cost of the regulation, I divide the total SEC budget (\$10.03B) by the number of enforcement actions during the sample period $(9,210)$. Therefore, a rough estimate of the cost per enforcement action is about 1.09 million dollars. Note that this estimate likely exceeds the true cost of foreign enforcement as this includes the cost of non-enforcement related activities. The estimated valuation benefit provided by SEC enforcement actions is, on average, 4.10 basis points daily. Given that the portfolio value is in excess of $\$ 1.2$ trillion dollar of market capitalization, the increase in market value is roughly $\$ 49$ million daily. Even on a daily basis, this clearly exceeds the cost of SEC enforcement by a wide margin. Note that the costs of enforcement are borne domestically while the benefits may be realized globally. 


\section{CHAPTER VII}

\section{CONCLUSION}

This study assesses the valuation impact of SEC enforcement action on the share prices of non-target foreign firms. I evaluate the premise that SEC enforcement oversight reduces investment risks and capital costs, and consequently enhances market values of firms. Prior studies conclude that the SEC follows a hands-off policy toward foreign firms, thereby reducing or eliminating the potential valuation benefits of legal bonding. However, SOX, budgetary increases at the SEC, and the events of September $11^{\text {th }}$ (post2002) are associated with a surge of SEC enforcement actions against foreign firms. This more recent regime of active and aggressive SEC enforcement enhances the credibility of the legal bonding premise, and also provides an archive of data useful for evaluating the valuation impacts of the SEC enforcement intensity (by studying the share prices of nontarget foreign firms).

I find that the SEC enforcement intensity of foreign firms has increased profoundly, and that these more frequent SEC actions confer significant positive abnormal returns to non-target foreign firms. Moreover, I show that the magnitudes of such returns are associated with country-specific characteristics that measure the strength of various aspects of a nation's regulatory system. Firms from weak home legal environments reap the greatest returns from the SEC action announcements. Finally, the magnitude of the response declines over time, consistent with the market adjusting to the new enforcement regime. Ultimately, the results imply that enforcement intensity is at least in part a driver of the cost of capital reduction for firms who can stand up to increased scrutiny. Although some prior research disputes the assignment of measured 
increases in valuation to the bonding hypothesis, results from this study cannot be explained by market segmentation reductions (because no systematic changes to investment barriers are expected to be correlated with enforcement action announcements), or other changes taking place at the time of the secondary listing.

In addition to the bonding question, this study is relevant to concurrent debates in public discussions and the accounting policies literature. These results are consistent with the intuition of Doidge et al. (2009), Leuz (2007), and Coffee (2007) who suggest that the Sarbanes-Oxley Act is not the culprit for a slowdown in cross-listings in the US. A complementary explanation suggests that as the legal landscape became more formidable for existing cross-listed firms, firms with marginal reporting and governance quality who were considering a cross-listing were intimidated, leaving other countries' exchanges to cater to such lower quality firms intending to cross-list (Piotroski and Srinivasan 2007). ${ }^{36}$

Although the findings in this study document a positive impact of SEC enforcement actions on the share values of non-target foreign firms, the implications for the wealth impact of legal bonding, and increased regulatory oversight in general, should be drawn cautiously. The legal system to which foreign firms may adhere embraces a variety of regulatory protections with potential for positive and negative impacts on security valuations. ${ }^{37}$ Adhering to a legal system with multiple aspects undoubtedly includes some legal components that presently are overly burdensome, and other components that enable reduced capital costs and higher share values. The empirical

\footnotetext{
${ }^{36}$ In fact, of the 59 sample firms examined by Doidge et al. (2009) who delisted, more than $20 \%$ (12 firms) were former targets of SEC enforcement (9) or class action lawsuits (3).

${ }^{37}$ For example, the findings in Licht et al. (2011) that a reduction in potential civil liability has a positive impact on share values does not necessarily conflict with my findings that increased SEC enforcement activity is also associated with increased share values.
} 
results in this manuscript provide considerable support for the interpretation that SEC enforcement actions create shareholder value for non-target foreign firms. 


\section{APPENDIX A}

\section{VARIABLE DEFINITIONS AND MODEL SPECIFICATION}

Model (1):

SEC_ACTION $N_{i t}=\alpha_{0}+\alpha_{1}$ POST $+\alpha_{2}$ CLASS_ACTION ${ }_{i t}+\alpha_{3}$ MB $_{i t-1}+\alpha_{4}$ SIZE $_{i t-1}+$ $\alpha_{5}$ RETURN $_{i t-1}+\alpha_{6}$ SKEW $_{i t-1}+\alpha_{7}$ TURNOVER $_{\text {it-1 }}+\varepsilon_{\text {eit }}$

\section{Where:}

SEC_ACTION $N_{i t}=$ indicator equal to ' 1 ' when SEC files enforcement action, ' 0 ' otherwise $P O S T$ = indicator equal to ' 1 ' after year 2001, ' 0 ' otherwise

CLASS_ACTION $N_{i t}=$ indicator equal to ' 1 ' if class action lawsuit was filed against firm ' $i$ ' in the previous 5 years, ' 0 ' otherwise

$M B_{i t-1}=$ firm $i$ 's beginning of year market-to book ratio

$S I Z E_{i t-1}=$ natural log of firm i's beginning of year total assets

$R E T U R N_{i t-1}=$ cumulative monthly market-adjusted return in year $\mathrm{t}-1$

$S K E W_{i t-1}=$ skewness of cumulative monthly market-adjusted return

TURNOVER $R_{i t-1}=$ cumulative percentage of firm ' $i$ '” share turnover in year ' $t-1$ '

$\varepsilon_{\text {eit }}=$ the residual

\section{Model (2):}

$A R B P_{\text {eit }}=\beta_{0}+\beta_{1} E_{\text {EVNT }}+\beta_{2}$ EVENT*RULE_LAW_RANK $_{i}+\beta_{3} R U L E \_L A W_{-} R A N K+\beta_{4}$ CHRON $_{e}+\beta_{5}$ REST $_{e}+\beta_{6}$ FCPA $_{e}+\beta_{7}$ MISC $_{e}+\beta_{8}$ CHRON $^{*} C A P_{e}+\beta_{9} E V E T * P H A T_{e i}+\bar{\beta}_{10} P H A T_{i}+\beta_{11}$ EVENT $^{*}$ SIZE $_{e i}+\beta_{12}$ EVENT $^{*} \mathrm{BM}_{e i}+\beta_{13}$ EVENT $^{*} H I_{-} P R O B_{e i}+\beta_{14} H I \_P R O B_{i}+\beta_{15}$ EVENT*CO_MATCH ${ }_{e i}+\beta_{16} E V E N T * I N D \_M A T C H_{e i}+\beta_{17} E V E N T * E X C H G \_M A T C H_{e i}+$ $\beta_{k}$ CONTROLS $+\mu_{\text {eit }}$

Where:

$A R B P_{\text {eit }}=$ Value-weighted CRSP-adjusted abnormal return (in basis points) ${ }^{38}$

$E V E N T_{e}=$ indicator equal to ' 1 ' within event period, ' 0 ' otherwise

$E V E N T^{*}=$ denotes interaction with event dummy

$R U L E \_L A W \_R A N K_{e}=$ the percentile rank of the strength of the rule of law in the home country of firm $i$ as measured by the Kaufmann et al (2010) indices

$\mathrm{CHRON}_{e}=$ date of the enforcement action, measured in days past the year 1960 (for programming convenience)

$R E S T_{e}=$ indicator equal to ' 1 ' for restatement events, ' 0 ' otherwise

$F C P A_{e}=$ indicator equal to ' 1 ' for FCPA events, ' 0 ' otherwise

$M I S C_{e}=$ indicator equal to ' 1 ' for miscellaneous events, ' 0 ' otherwise

$C A P_{e}=$ annual earnings response coefficient estimated annually (see Appendix B)

$P_{H A T_{e i}}=$ estimated SEC enforcement probability from Model (1)

$H I_{-} P R O B_{e i}=$ indicator equal to ' 1 ' if estimated SEC enforcement probability is in the highest quintile, ' 0 ' otherwise

$C O \_M A T C H_{e i}=$ indicator equal to ' 1 ' when firm ' $i$ ' shares the same home country as the target firm, ' 0 ' otherwise

IND_MATCH ${ }_{e i}=$ indicator equal to ' 1 ' when firm ' $i$ ' shares the same (GICs) industry as the target firm, ' 0 ' otherwise

EXCHG_MATCH ${ }_{e i}=$ indicator equal to ' 1 ' when firm ' $i$ ' shares the same exchange as the target firm, ' 0 ' otherwise

$\mu_{\text {eit }}=$ the residual

${ }^{38}$ Note: e, i, and t subscripts denote event 'e', firm 'i', and time 't' respectively. 


\section{CONTROLS:}

$S I Z E_{i}=$ natural $\log$ of firm $i$ 's beginning of year total assets

$M B_{i}=$ firm $i$ 's beginning of year market-to book ratio

Y, I, C, E=Year, Industry, Country, Event fixed effects 


\section{APPENDIX B}

\section{CAPITALIZATION RATE ESTIMATION}

To proxy for varying capitalization rates during the sample period, I estimate Model (3) by pooling the quarterly earnings announcements annually. I use the earnings repose coefficient (ERC) as an estimate for the capitalization rate. I start will all firms (U.S. and foreign) with the required information for Model (3) from the intersection of COMPUSTAT, IBES, and CRSP. I eliminate firms that do not have this information for all four quarters in each of the 16 sample years so that changing sample composition is not responsible for varying capitalization rates over time. This requirement provides a sample of 224 firms (896 observations per year) during each year of the sample period. I include controls for time varying factors that affect earnings response coefficients. Specifically, I allow for differential slopes and intercepts when earnings is negative as prior research has documented a weaker earnings-return relation when earnings are negative (Hayne 1995). I also allow for differential responses to earnings based upon: (a) capitalization decile (SIZE_DEC), (b) forecast dispersion, measured by the standard deviation of IBES analysts' consensus forecast (SDEV_E ), because ERC's are related to forecast precision (Burghstahler and Chuk 2010), (c) extremity ( $H I$ and $L O$ ) because of the non-linearity of the return earnings relation (Freeman and Tse 1992), and (d) the market-to-book ratio (MB) as prior research indicates that higher growth is likely to increase the earnings response coefficient (ERC) (Collins and Kothar 1989). Preannouncement returns are included as a measurement error proxy to account for information that reaches the market after the analyst forecast release date but prior to the earnings announcement. On the following page, Panel A presents the results of the annual regressions while Panel B reports the estimated capitalization rate which becomes the 'CAP' variable in Model (2) and Table 5. ${ }^{\diamond}$ Observations with Studentized residuals greater than 3.0 in absolute value are removed from the reported results.

Model (3): $\quad C S A R_{i t}=\gamma_{0}+\gamma_{1} U E_{i t}+\gamma_{2} H I_{i t}+\gamma_{3} H I^{*} U E_{i t}+\gamma_{4} L O_{i t}+\gamma_{5} L O^{*} U E_{i t}+\gamma_{6} L_{O S S}+\gamma_{7} L_{\text {LSS }} * U E_{i t}+$ $\gamma_{8} S I Z E_{-} D E C_{i t}+\gamma_{9} S I Z E \_D E C * U E_{i t}+\gamma_{10} S D E V \_E_{i t}+\gamma_{11} S D E V \_E * U E_{i t}+\gamma_{12} M B_{i t}+\gamma_{13} M B^{*} U E_{i t}+$ $\gamma_{14} P R E \_A N N O U N C E \_R E T_{i t}+\eta_{i t}$

Where:

$C S A R=5$-day $((-1,+3)$ relative to earnings announcement date) cumulative size-adjusted abnormal returns for firm ' $i$ ' at time ' $t$ '

$U E=$ firm $i$ 's actual quarterly EPS (from I/B/E/S) less I/B/E/S mean analyst forecast, scaled by price at the beginning of the quarter

$H I=$ indicator equal to ' 1 ' if UE is in the extreme top $10 \%$ of the sample UE distribution

$L O=$ indicator equal to ' 1 ' if $\mathrm{UE}$ is in the extreme bottom $10 \%$ of the sample UE distribution

LOSS = indicator equal to ' 1 ' if EPS is negative, ' 0 ' otherwise

$S I Z E \_D E C=$ capitalization decile of firm ' $i$ ' at time ' $t$ ' from CRSP

$S D E V \_E$ =the standard deviation of expected earnings from IBES summary data

$\mathrm{MB}=$ beginning of the year market to book ratio

\footnotetext{
${ }^{\diamond}$ To cross-validate these estimates, I regress $\hat{\gamma}_{1}$ on the annual 10-year U.S. Treasury bill rate and interest rate spread between 'AAA' and 'BBB' credit ratings. Unreported results indicate a significant positive (negative) relationship with the quality spread (U.S. Treasury bill rates), consistent with theoretical expectations (see Collins and Kothari 1989).
} 
PRE_ANNOUNCE_RET = cumulative abnormal return from date of analyst forecast to day -2 relative to the earnings announcement date $\eta_{\text {eit }}=$ the residual

\begin{tabular}{|c|c|c|c|c|c|c|c|c|c|}
\hline \multicolumn{10}{|c|}{ Panel A: 16-year Annual Cross-Sections } \\
\hline \multirow{3}{*}{$\begin{array}{l}\text { Coefficient } \\
\text { (Standard Err) } \\
\text { Yrs Positive }\end{array}$} & $\gamma_{0}$ & $\gamma_{1}$ & $\gamma_{2}$ & $\gamma_{3}$ & $\gamma_{4}$ & $\gamma_{5}$ & $\gamma_{6}$ & $\gamma_{7}$ & $\gamma_{8}$ \\
\hline & $\begin{array}{c}0.01 \\
(0.01)\end{array}$ & $\begin{array}{c}10.07^{* * * *} \\
(1.44)\end{array}$ & $\begin{array}{l}0^{0.03} \\
(0.01)\end{array}$ & $\begin{array}{c}-7.73^{* * * *} \\
(1.05)\end{array}$ & $\begin{array}{c}-0.01 \\
(0.01)\end{array}$ & $\begin{array}{c}-1.90^{* * *} \\
(0.83)\end{array}$ & $\begin{array}{c}-0.01^{* * * *} \\
(0.00)\end{array}$ & $\begin{array}{c}-6.15^{* * *} \\
(1.17)\end{array}$ & $\begin{array}{c}0.00 \\
(0.00)\end{array}$ \\
\hline & 9 & 16 & 13 & 0 & 5 & 4 & 1 & 1 & 5 \\
\hline \multicolumn{10}{|c|}{ Panel B: Estimated Capitalization Rates $\left(\widehat{\gamma}_{1}\right)$ By Year } \\
\hline 1995 & \multicolumn{4}{|c|}{5.98} & & 2003 & \multicolumn{2}{|c|}{7.63} & \\
\hline 1996 & \multicolumn{2}{|c|}{0.97} & & & & 2004 & \multicolumn{2}{|c|}{10.92} & \\
\hline 1997 & \multicolumn{2}{|c|}{10.09} & & & & 2005 & \multicolumn{2}{|c|}{10.67} & \\
\hline 1998 & \multicolumn{2}{|c|}{16.51} & & & & 2006 & \multicolumn{2}{|c|}{19.02} & \\
\hline 1999 & \multicolumn{2}{|c|}{0.39} & & & & 2007 & \multicolumn{2}{|c|}{10.20} & \\
\hline 2000 & \multicolumn{2}{|c|}{14.71} & & & & 2008 & \multicolumn{2}{|c|}{17.37} & \\
\hline 2001 & \multicolumn{2}{|c|}{0.96} & & & & 2009 & \multicolumn{2}{|c|}{10.20} & \\
\hline 2002 & \multicolumn{2}{|c|}{14.32} & & & & 2010 & \multicolumn{2}{|c|}{11.13} & \\
\hline
\end{tabular}




\section{Table 1: Enforcement Sample Description}

Panels A and B describe the SEC enforcement of foreign firms listed in U.S. market over time and by listing type, each partitioned by enforcement category. ${ }^{a}$ I split the data into two time periods (1995-2001 and 2002-2010). Panel C reports foreign SEC enforcement actions as a percentage of total actions of that type since 2002. The denominator is 212 for insider trading, 824 for restatements, 89 for FCPA violations, and because the comparable domestic enforcement is not clearly defined for the miscellaneous category, no

percentages are reported. As a reference point, I report the foreign firms as a percentage of U.S. market (as of April 2010).

Panel A: SEC Enforcements Over Time

Total Sample Insider Trading

Restatements

FCPA

Miscellaneous

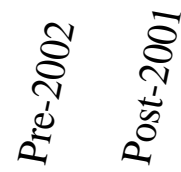

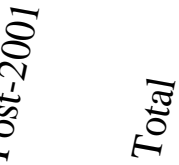

$28 \quad 144$

$\begin{array}{cc}16 & 36 \\ 5 & 70\end{array}$

70

70
20

7
Panel B: SEC by Listing Type

\begin{tabular}{|c|c|c|}
\hline 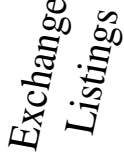 & $\stackrel{0}{0}$ & 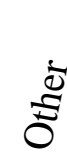 \\
\hline 151 & 12 & $\mathrm{~g}$ \\
\hline 47 & 3 & \\
\hline 65 & 6 & \\
\hline 19 & 0 & \\
\hline 20 & 3 & \\
\hline
\end{tabular}

Panel C: Proportion of Foreign

SEC Enforcement Actions (Post-2001)*

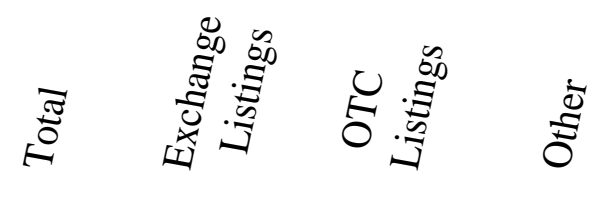

$\begin{array}{cccc}16.98 \% & 14.62 \% & 1.42 \% & 0.94 \% \\ 8.50 \% & 7.28 \% & 0.73 \% & 0.49 \%\end{array}$

$22.47 \% \quad 21.35 \% \quad 0.00 \% \quad 1.12 \%$

*Foreign Firms as a Percent of U.S. Market

${ }^{a}$ I confine the Insider Trading sample to cases in which the SEC charges a firm insider because I am interested in pursuit of firms.

Therefore, I exclude cases in which the insiders are unassociated with any firm (for example, see

http://www.sec.gov/litigation/litreleases/lr19212.htm). Roughly 40\% of all insider trading cases fall into this category. I also exclude

firms from the restatement sample if I cannot identify the firms and their status as foreign or domestic. 
Table 2: Sample Representation by Country

\begin{tabular}{|c|c|c|c|c|c|c|c|c|c|c|}
\hline Country & Firms & $\begin{array}{l}\text { Firm- } \\
\text { years }\end{array}$ & $\begin{array}{l}\text { Percent of Firm- } \\
\text { years with } \\
\text { Enforcement }\end{array}$ & & & & & & $\begin{array}{c}\text { Code } \\
\text { Law }\end{array}$ & $\begin{array}{c}\text { Average } \\
\text { KKM } \\
\text { Rule of } \\
\text { Law } \\
\text { Ranking }\end{array}$ \\
\hline ANTIGUA AND BARBUDA & 1 & 6 & - & & & & & 0 & - & 42 \\
\hline ARGENTINA & 18 & 169 & - & & & & & 0 & 1 & 40 \\
\hline AUSTRALIA & 39 & 277 & $1.08 \%$ & 2 & 1 & & & 3 & 0 & 95 \\
\hline AUSTRIA & 1 & 8 & - & & & & & 0 & 1 & 98 \\
\hline BAHAMAS & 5 & 45 & - & & & & & 0 & - & 88 \\
\hline BELGIUM & 6 & 32 & $3.13 \%$ & & 1 & & & 1 & 1 & 88 \\
\hline BELIZE & 1 & 11 & - & & & & & 0 & - & 57 \\
\hline BERMUDA & 109 & 767 & $1.96 \%$ & 5 & 8 & 1 & 1 & 15 & - & 81 \\
\hline BOLIVIA & 1 & 1 & - & & & & & 0 & - & 49 \\
\hline BRAZIL & 17 & 112 & $2.68 \%$ & 3 & & & & 3 & 1 & 44 \\
\hline BRITISH VIRGIN ISLANDS & 37 & 239 & $2.09 \%$ & 1 & 4 & & & 5 & - & 66 \\
\hline CANADA & 525 & 3,280 & $1.13 \%$ & 4 & 24 & & 9 & 37 & 0 & 95 \\
\hline CAYMAN ISLANDS & 105 & 469 & $0.64 \%$ & 2 & 1 & & & 3 & - & 63 \\
\hline CHILE & 29 & 291 & $0.34 \%$ & & 1 & & & 1 & 1 & 87 \\
\hline CHINA & 24 & 180 & $1.67 \%$ & 1 & 2 & & & 3 & - & 43 \\
\hline COLOMBIA & 1 & 5 & - & & & & & 0 & 1 & 23 \\
\hline CYPRUS & 1 & 3 & $66.67 \%$ & & 2 & & & 2 & - & 87 \\
\hline DENMARK & 7 & 65 & $3.08 \%$ & 1 & & 1 & & 2 & 1 & 98 \\
\hline DOMINICAN REPUBLIC & 1 & 7 & - & & & & & 0 & - & 36 \\
\hline FINLAND & 8 & 60 & - & & & & & 0 & 1 & 99 \\
\hline FRANCE & 42 & 343 & $2.04 \%$ & & 4 & 3 & & 7 & 1 & 90 \\
\hline GERMANY & 33 & 228 & $4.82 \%$ & 4 & & 2 & 5 & 11 & 1 & 93 \\
\hline GHANA & 1 & 7 & - & & & & & 0 & - & 47 \\
\hline GREECE & 9 & 51 & $1.96 \%$ & & & & 1 & 1 & 1 & 74 \\
\hline HONG KONG & 17 & 112 & - & & & & & 0 & 0 & 80 \\
\hline HUNGARY & 1 & 13 & - & & & & & 0 & 1 & 78 \\
\hline INDIA & 17 & 122 & - & & & & & 0 & 0 & 57 \\
\hline INDONESIA & 4 & 39 & $2.56 \%$ & & 1 & & & 1 & 1 & 29 \\
\hline IRELAND & 27 & 234 & $1.28 \%$ & 1 & 2 & & & 3 & 0 & 93 \\
\hline ISRAEL & 139 & 1,137 & $0.88 \%$ & 3 & 7 & & & 10 & 0 & 81 \\
\hline ITALY & 19 & 164 & $4.88 \%$ & 3 & 3 & 2 & & 8 & 1 & 73 \\
\hline JAPAN & 39 & 428 & $1.17 \%$ & 1 & 2 & & 2 & 5 & 1 & 88 \\
\hline JORDAN & 1 & 4 & - & & & & & 0 & 1 & 63 \\
\hline KOREA, SOUTH & 17 & 119 & - & & & & & 0 & 1 & 77 \\
\hline LIBERIA & 6 & 63 & $3.17 \%$ & 1 & 1 & & & 2 & - & 60 \\
\hline LUXEMBOURG & 20 & 142 & - & & & & & 0 & 1 & 96 \\
\hline MARSHALL ISLANDS & 28 & 132 & - & & & & & 0 & - & 71 \\
\hline MEXICO & 61 & 442 & $1.58 \%$ & 6 & & & 1 & 7 & 1 & 39 \\
\hline NETHERLANDS & 55 & 450 & $2.44 \%$ & 5 & 3 & 1 & 2 & 11 & 1 & 96 \\
\hline NETHERLANDS ANTILLES & 6 & 68 & - & & & & & 0 & - & 96 \\
\hline NEW ZEALAND & 11 & 55 & - & & & & & 0 & 0 & 98 \\
\hline NORWAY & 13 & 81 & $1.23 \%$ & & & 1 & & 1 & 1 & 99 \\
\hline PANAMA & 6 & 62 & $1.61 \%$ & & & 1 & & 1 & - & 49 \\
\hline PAPUA NEW GUINEA & 1 & 15 & - & & & & & 0 & - & 20 \\
\hline PERU & 3 & 22 & - & & & & & 0 & 1 & 31 \\
\hline PHILIPPINES & 4 & 32 & - & & & & & 0 & 1 & 43 \\
\hline POLAND & 2 & 5 & - & & & & & 0 & 1 & 71 \\
\hline PORTUGAL & 4 & 35 & - & & & & & 0 & 1 & 86 \\
\hline PUERTO RICO & 1 & 3 & - & & & & & 0 & - & 72 \\
\hline RUSSIA & 6 & 57 & - & & & & & 0 & - & 20 \\
\hline SINGAPORE & 10 & 85 & - & & & & & 0 & 0 & 88 \\
\hline SOUTH AFRICA & 21 & 142 & - & & & & & 0 & 0 & 55 \\
\hline SPAIN & 9 & 91 & $1.10 \%$ & 1 & & & & 1 & 1 & 87 \\
\hline SWEDEN & 22 & 128 & $0.78 \%$ & & & 1 & & 1 & 1 & 97 \\
\hline SWITZERLAND & 23 & 219 & $7.76 \%$ & 5 & 4 & 5 & 3 & 17 & 1 & 98 \\
\hline TAIWAN & 10 & 73 & $1.37 \%$ & & 1 & & & 1 & 1 & 77 \\
\hline TURKEY & 1 & 10 & - & & & & & 0 & 1 & 54 \\
\hline UNITED KINGDOM & 153 & 1,039 & $0.87 \%$ & 3 & 3 & 2 & 1 & 9 & 0 & 94 \\
\hline VENEZUELA & 3 & 23 & - & & & & & 0 & 1 & 22 \\
\hline
\end{tabular}


Table 3: Probability of SEC Enforcement

This table provides the results of seven logistic regressions that model the SEC's enforcement choice. The sample is comprised of all foreign firms listed in U.S. markets. Panel A estimates the probability of enforcement for the entire sample, the pre- and post- periods, and the results of the joint test that all coefficients are equal across the two time periods (indicated by "Chi-Square Test"). Panel B separates the probability of enforcement by type.

The number of actions is different than Table 1 because of data requirements and because enforcement actions can target multiple firms.

\section{Panel A: All Enforcements}

\begin{tabular}{|c|c|c|c|c|c|c|c|c|c|}
\hline \multirow[b]{2}{*}{ Parameter } & \multicolumn{3}{|c|}{$1995-2010$} & \multicolumn{2}{|c|}{$1995-2001$} & \multicolumn{2}{|c|}{$2002-2010$} & & \\
\hline & & \multicolumn{2}{|c|}{$\overline{\text { Estimate Odds Ratio }}$} & \multicolumn{2}{|c|}{ Estimate Odds Ratio } & \multicolumn{2}{|c|}{ Estimate Odds Ratio } & & \\
\hline$\overline{P O S T}$ & $+(H 1)$ & $1.45^{4 \pi}$ & 4.25 & & & & & & \\
\hline CLASS_ACTION & + & $1.16^{* \pi *}$ & 3.19 & 1.4 & 4.04 & $1.13^{* * *}$ & 3.09 & & \\
\hline MB & ? & $0.00^{* *}$ & 1.00 & 0.00 & 1.00 & $0.00^{* * *}$ & 1.00 & & \\
\hline SIZE & ? & $0.27^{* * *}$ & 1.31 & 0.09 & 1.09 & $0.28^{* * *}$ & 1.32 & & \\
\hline RETURN & ? & 0.34 & 1.4 & $0.44^{* * *}$ & 1.56 & 0.27 & 1.31 & & \\
\hline SKEW & - & $-0.23^{*}$ & 0.79 & $-0.67^{* * *}$ & 0.51 & -0.18 & 0.84 & & \\
\hline TURNOVER & + & 0.00 & 1.01 & -0.1 & 0.9 & 0.00 & 1.00 & & \\
\hline Intercept & & $-8.22^{* * *}$ & & $-6.72^{* * *}$ & & $-6.86^{* * *}$ & & & \\
\hline \multicolumn{4}{|l|}{ Chi-Square Test (p-value) } & \multicolumn{4}{|c|}{$11.74^{* *}(\mathrm{p}=.03)$} & & \\
\hline N (Number of Actions) & & 12,474 & $(156)$ & 4,909 & $(11)$ & 7,565 & $(145)$ & & \\
\hline Pseudo- $\mathrm{R}^{<}$ & & 0.17 & & 0.09 & & 0.14 & & & \\
\hline Area Under ROC Curve & & 0.84 & & 0.7 & & 0.8 & & & \\
\hline \multicolumn{10}{|c|}{ Panel B: By Enforcement Type } \\
\hline \multirow[b]{2}{*}{ Parameter } & & \multicolumn{2}{|c|}{ Insider Trading } & \multicolumn{2}{|c|}{ Restatement } & \multicolumn{2}{|c|}{ FCPA $^{b}$} & Misce & laneous \\
\hline & & \multicolumn{2}{|c|}{$\overline{\text { Estimate Odds Ratio }}$} & \multicolumn{2}{|r|}{$\overline{\text { Odds Ratio }}$} & \multicolumn{2}{|c|}{ Odds Ratio } & & $\overline{\text { Odds Ratio }}$ \\
\hline$\overline{P O S T}$ & $+($ H1) & -0.23 & 0.8 & $3.35^{*}$ & 28.41 & $2.49^{*}$ & 12.08 & 0.79 & 7.79 \\
\hline CLASS_ACTION & + & $1.92^{* * *}$ & 6.84 & $1.64^{* * \pi}$ & 5.18 & $1.18^{*}$ & 3.25 & 0.25 & 2.36 \\
\hline MB & ? & 0.00 & 1.00 & $0.00^{* * *}$ & 1.00 & 0.01 & 1.01 & -0.01 & 1.01 \\
\hline SIZE & ? & $0.38^{* * *}$ & 1.46 & 0.13 & 1.14 & $0.41^{* * *}$ & 1.51 & $0.85^{* * *}$ & 2.82 \\
\hline RETURN & ? & $0.57^{* * *}$ & 1.77 & -0.18 & 0.83 & -1.00 & 0.37 & $1.11^{* * *}$ & 4.21 \\
\hline SKEW & - & -0.12 & 0.89 & $-0.29^{* * *}$ & 0.75 & $-0.47^{* * *}$ & 0.63 & 0.37 & 2.18 \\
\hline TURNOVER & + & 0.00 & 1.00 & 0.00 & 1.00 & -0.01 & 1.01 & -0.01 & 1.09 \\
\hline Intercept & & $-9.49^{* * *}$ & & $-9.46^{* * *}$ & & $-12.34^{* * *}$ & & $-15.56^{* * *}$ & \\
\hline N (Number of Actions) & & 10,772 & (31) & 11,330 & (63) & 10,588 & (16) & 10,828 & $(46)$ \\
\hline Pseudo- $\mathrm{R}^{<}$ & & 0.18 & & 0.16 & & 0.27 & & 0.36 & \\
\hline Area Under ROC Curve & & 0.79 & & 0.85 & & 0.85 & & 0.91 & \\
\hline
\end{tabular}

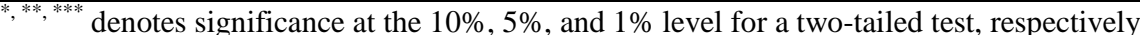

b-The Firth procedure was applied to reduced coefficient bias due to complete separation (“monotone likelihood”) (Firth 1993; Heinz and Schemper 2002). 
Table 4: Non-Target Foreign Firm Market Returns around Enforcement Announcement Dates

This table provides the market-adjusted returns (in basis points) to portfolios of firms centered on announcement dates of SEC enforcement of foreign firms. Unless noted otherwise, portfolio membership includes all foreign firms with requisite stock price data to compute abnormal returns. The Foreign-other category consists of foreign firms listed only in the U.S. Standard errors and t-statistics treat each event as one observation (similar to Fama and MacBeth (1973)). The simulated p-values reported for 'All Years' is described in Appendix A. Because stock price movements greater than 10\% are likely to be due to firm-specific information that is unrelated to enforcement, I remove observations with daily returns greater than $10 \%$ in absolute value. One enforcement action that occurs late in year 2010, leaving 171 actions, because the daily return window extends into year 2011 (this data is unavailable in CRSP). I also discard one outlying extreme observation from the (-14,-2) window in the 1995-2001 time period.

\section{Panel A: Non-Target Foreign Firm Returns}

\section{Market Adjusted Returns}

\begin{tabular}{cccccccccccc}
\multicolumn{1}{c}{ 1995-2001 } & \multicolumn{1}{c}{ 2002-2010 } & \multicolumn{4}{c}{ All Years } \\
\hline Window & N & Return & t & N & Return & t & N & Return & t & $\begin{array}{c}\text { Simulated } \\
\text { p-value }\end{array}$ \\
\hline$(-14,-2)$ & 27 & -12.2 & -0.39 & 143 & 0.9 & 0.17 & 171 & 0.0 & -0.09 & 0.620 \\
$(-1,8)$ & 28 & -1.8 & -0.26 & 143 & $51.7^{* * *}$ & 3.64 & 171 & $41.1^{* * *}$ & 3.04 & 0.008 \\
$(9,20)$ & 28 & -0.1 & -0.31 & 143 & 14.7 & 1.17 & 171 & 0.1 & 0.19 & 0.591
\end{tabular}

Panel B: By Listing Type

\section{0-day Market Adjusted Returns}

\begin{tabular}{llllllllllll}
\hline Cross-listed & $(-1,8)$ & 28 & -0.6 & -0.14 & 143 & $64.2^{* * *}$ & 4.42 & 171 & $52.2^{* * *}$ & 3.72 & 0.004 \\
Foreign-other & $(-1,8)$ & 28 & -14.0 & -0.35 & 143 & $39.4^{* * *}$ & 2.44 & 171 & $30.7^{* *}$ & 2.00 & 0.029
\end{tabular}

Panel C: By Type of Violation

\begin{tabular}{|c|c|c|c|c|c|c|c|c|c|c|c|}
\hline Insider Trading & $(-1,8)$ & 16 & -36.0 & -1.02 & 36 & 28.2 & 1.09 & 52 & 8.4 & 0.36 & 0.561 \\
\hline Restatements & $(-1,8)$ & 5 & 61.1 & 0.53 & 70 & $34.1^{* *}$ & 1.88 & 75 & $36.5^{*}$ & 1.74 & 0.096 \\
\hline FCPA & $(-1,8)$ & 0 & - & - & 19 & $101.7^{* * *}$ & 3.04 & 19 & $101.7^{* * *}$ & 3.04 & 0.000 \\
\hline Miscellaneous & $(-1,8)$ & 7 & -0.0 & -0.02 & 18 & $107.0^{* *}$ & 2.50 & 25 & $76.3^{*}$ & 1.70 & 0.036 \\
\hline
\end{tabular}

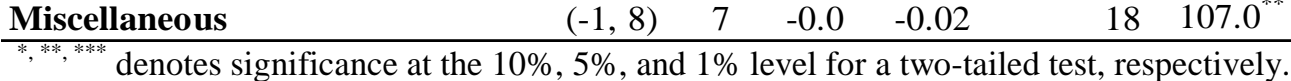


Table 5: Panel Regression Analysis of SEC Enforcement

This table reports results of pooled time-series cross-sectional regression where the dependent variable is ARBP, the daily abnormal return of firm ' $i$ ' on day ' $t$ ' in basis points. The $E V E N T^{*}$ prefix indicates that the variable of interest has been interacted with the event indicator. Only the first enforcement events are included in cases where a firm is subject to multiple enforcement actions. All specifications include controls for market-to book and size, as well as fixed effects for country (C), industry (I) and year (Y): see Appendix A for details. All continuous variables are winsorized at the $1 \%$ level, ARBP is truncated at $\pm 1,000$ ( $\pm 10 \%$ in percentage terms) and repeat events are discarded. Regressions (2), (3), and (4) also include fixed effects for each event to purge event specific variation. RULE_LAW_RANK is the percentile rank of the strength of the rule of law in the home country of firm $i$ as measured by the Kaufmann et al (2010) indices. Variables with the prefix EVENT* represent an interaction of the event dummy and the corresponding variable. Note that in specifications that include event interactions, the main effects of the EVENT dummy are not interpretable because it is a function of the dummy variable coding for each event. Coefficient estimates are in bold and standard errors are reported below. Reported standard errors are double-clustered by firm and date. 


\begin{tabular}{|c|c|c|c|c|c|c|c|c|c|c|}
\hline Parameter & $\begin{array}{c}\text { Expected } \\
\text { Sign }\end{array}$ & (1) & $(2)$ & (3) & (4) & (5) & (6) & (7) & (8) & (9) \\
\hline EVENT & $+(\mathrm{H} 2)$ & $\begin{array}{c}4^{4.10}{ }^{* *} \\
2.49\end{array}$ & $\begin{array}{c}6.28^{*} \\
3.98\end{array}$ & $\begin{array}{c}9.26{ }^{* *} \\
4.63\end{array}$ & $\begin{array}{c}16.45^{* * * *} \\
5.92\end{array}$ & $\begin{array}{r}\mathbf{1 8 . 0 9}^{*} \\
14.05\end{array}$ & $\begin{array}{c}\mathbf{1 7 . 6 5} \\
14.56\end{array}$ & $\begin{array}{c}\mathbf{2 5 . 3 9}^{\text {*** }} \\
14.87\end{array}$ & $\begin{array}{c}\mathbf{2 4 . 7 1}^{* *} \\
14.88\end{array}$ & $\begin{array}{c}\mathbf{2 4 . 9 7}^{* *} \\
14.88\end{array}$ \\
\hline$E V E N T^{*} R U L E \_L A W \_R A N K$ & - (H3) & & $\begin{array}{c}-\mathbf{8 . 0 0}^{* *} \\
4.17\end{array}$ & & $\begin{array}{c}-7.95^{* *} \\
3.92\end{array}$ & $\begin{array}{c}-7.41^{* *} \\
3.89\end{array}$ & $\begin{array}{c}\mathbf{- 8 . 0 6}^{* * *} \\
3.83\end{array}$ & $\begin{array}{c}\mathbf{- 8 . 0 3}^{\text {** }} \\
3.84\end{array}$ & $\begin{array}{c}-7.97^{* *} \\
3.80\end{array}$ & $\begin{array}{c}-\mathbf{7 . 5 4} \\
3.87\end{array}$ \\
\hline$R U L E \_L A W \_R A N K$ & ? & & $\begin{array}{c}\mathbf{0 . 3 6} \\
0.64\end{array}$ & & $\begin{array}{c}\mathbf{0 . 1 4} \\
0.46\end{array}$ & $\begin{array}{c}\mathbf{- 0 . 1 6} \\
3.06\end{array}$ & $\begin{array}{c}\mathbf{0 . 1 2} \\
3.10\end{array}$ & $\begin{array}{c}\mathbf{0 . 2 1} \\
3.12\end{array}$ & $\begin{array}{c}\mathbf{0 . 1 8} \\
3.06\end{array}$ & $\begin{array}{c}\mathbf{- 0 . 0 5} \\
3.15\end{array}$ \\
\hline CHRON & - (H4) & & & $\begin{array}{c}-\mathbf{0 . 0 7} \\
0.04\end{array}$ & $\begin{array}{c}\mathbf{- 0 . 0 8}^{*} \\
0.04\end{array}$ & $\begin{array}{c}\mathbf{- 8 . 4 7} \\
6.87\end{array}$ & $\begin{array}{c}\mathbf{- 8 . 4 8} \\
6.87\end{array}$ & $\begin{array}{c}\mathbf{- 8 . 4 8} \\
6.87\end{array}$ & $\begin{array}{c}\mathbf{- 8 . 4 8} \\
6.87\end{array}$ & $\begin{array}{c}\mathbf{- 8 . 3 9} \\
6.87\end{array}$ \\
\hline REST & ? & & & $\begin{array}{c}-2.58 \\
3.91\end{array}$ & $\begin{array}{c}-3.02 \\
4.01\end{array}$ & $\begin{array}{c}-\mathbf{2 7 . 5 0} \\
23.16\end{array}$ & $\begin{array}{c}-27.53 \\
23.16\end{array}$ & $\begin{array}{c}-27.53 \\
23.16\end{array}$ & $\begin{array}{c}-27.54 \\
23.16\end{array}$ & $\begin{array}{c}\mathbf{- 2 8 . 0 6} \\
23.16\end{array}$ \\
\hline FCPA & ? & & & $\begin{array}{c}\text { 11.11 }^{\text {** }} \\
5.17\end{array}$ & $\begin{array}{c}\mathbf{1 1 . 1 4}^{\text {** }} \\
5.31\end{array}$ & $\begin{array}{c}\mathbf{2 5 . 0 6} \\
20.04\end{array}$ & $\begin{array}{c}\mathbf{2 5 . 0 7} \\
20.04\end{array}$ & $\begin{array}{c}\mathbf{2 5 . 0 7} \\
20.04\end{array}$ & $\begin{array}{c}\mathbf{2 5 . 0 7} \\
20.04\end{array}$ & $\begin{array}{c}24.43 \\
20.04\end{array}$ \\
\hline MISC & $?$ & & & $\begin{array}{l}2.95 \\
5.96\end{array}$ & $\begin{array}{c}3.02 \\
6.07\end{array}$ & $\begin{array}{c}\mathbf{- 8 7 . 7 3} \\
70.43\end{array}$ & $\begin{array}{c}\mathbf{- 8 7 . 8 2} \\
70.43\end{array}$ & $\begin{array}{c}\mathbf{- 8 7 . 8 2} \\
70.43\end{array}$ & $\begin{array}{c}\mathbf{- 8 7 . 7 8} \\
70.43\end{array}$ & $\begin{array}{c}\mathbf{- 8 5 . 6 8} \\
70.49\end{array}$ \\
\hline CHRON*CAP & $?$ & & & & & $\begin{array}{c}-\mathbf{- 0 . 0 8} \\
0.08\end{array}$ & $\begin{array}{l}-\mathbf{- 0 . 0 8} \\
0.08\end{array}$ & $\begin{array}{c}\mathbf{- 0 . 0 8} \\
0.08\end{array}$ & $\begin{array}{c}\mathbf{- 0 . 0 8} \\
0.08\end{array}$ & $\begin{array}{c}\mathbf{- 0 . 0 8} \\
0.08\end{array}$ \\
\hline EVENT*PHAT & + & & & & & & $\begin{array}{l}\mathbf{4 . 7 9} \\
78.85\end{array}$ & $\begin{array}{c}\mathbf{1 8 6 . 7 6}^{\text {**** }} \\
56.32\end{array}$ & $\begin{array}{c}\mathbf{9 7 . 8 0}^{* * * *} \\
36.56\end{array}$ & $\begin{array}{c}\mathbf{1 0 3 . 2 3}^{\text {**** }} \\
36.67\end{array}$ \\
\hline PHAT & $?$ & & & & & & $\begin{array}{c}-\mathbf{3 7 0 . 0 4} \\
51.05\end{array}$ & $\begin{array}{c}\mathbf{- 4 1 9 . 1 1} \\
49.86\end{array}$ & $\begin{array}{c}-\mathbf{2 6 1 . 3 0} \\
35.35\end{array}$ & $\begin{array}{c}\mathbf{- 2 6 2 . 0 4}^{* * *} \\
35.37\end{array}$ \\
\hline EVENT*SIZE & - & & & & & & & $\begin{array}{c}-1.25 \\
0.42\end{array}$ & $\begin{array}{c}-1.17^{* * *} \\
0.44\end{array}$ & $\begin{array}{c}-\mathbf{1 . 2 8} \\
0.44\end{array}$ \\
\hline$E V E N T * B M$ & ? & & & & & & & $\begin{array}{c}\mathbf{- 0 . 0 2}^{\text {** }} \\
0.01\end{array}$ & $\begin{array}{c}\mathbf{- 0 . 0 2}^{\text {*** }} \\
0.01\end{array}$ & $\begin{array}{c}-\mathbf{0 . 0 2} \\
0.01\end{array}$ \\
\hline EVENT*HI_PROB & + & & & & & & & & $\begin{array}{c}\mathbf{2 . 9 2}^{* *} \\
1.48\end{array}$ & $\begin{array}{c}2.96^{* *} \\
1.48\end{array}$ \\
\hline HI_PROB & ? & & & & & & & & $\begin{array}{c}-\mathbf{7 . 2 8} \\
1.03\end{array}$ & $\begin{array}{c}-7.28 \\
1.03\end{array}$ \\
\hline EVENT*CO_MATCH & ? & & & & & & & & & $\begin{array}{c}6.57^{* *} \\
3.31\end{array}$ \\
\hline EVENT*IND_MATCH & $?$ & & & & & & & & & $\begin{array}{c}-\mathbf{1 1 . 6 5} \\
4.70\end{array}$ \\
\hline EVENT*EXCHG_MATCH & $?$ & & & & & & & & & $\begin{array}{c}\mathbf{4 . 7 4}^{* * * *} \\
1.53\end{array}$ \\
\hline \multirow[t]{2}{*}{ Intercept } & & -8.43 & $-54.87^{* * *}$ & $-29.17^{* * *}$ & $-31.98^{* * *}$ & 14.02 & 14.01 & 14.00 & 13.98 & 13.81 \\
\hline & & 8.71 & 5.63 & 7.54 & 6.97 & 11.41 & 11.54 & 11.54 & 11.54 & 11.54 \\
\hline F-value & & $33.75^{* * *}$ & $42.32^{* * *}$ & $33.93^{* * *}$ & $47.66^{* * *}$ & $27.67^{* * *}$ & $27.18^{* * *}$ & $28.15^{* * *}$ & $28.28^{* * *}$ & $28.23^{* * *}$ \\
\hline Observations & & $2,771,853$ & $2,771,853$ & $2,771,853$ & $2,763,439$ & $2,762,054$ & $2,757,329$ & $2,757,329$ & $2,757,329$ & $2,757,329$ \\
\hline Fixed Effects & & C,I,Y & E,I,Y & C,I,Y & $\mathrm{I}, \mathrm{Y}$ & E,C,I,Y & E,C,I,Y & E,C,I,Y & E,C,I,Y & E,C,I,Y \\
\hline
\end{tabular}


Figure 1: Foreign Enforcement as a Percentage of U.S. Enforcement

Figure 1 graphs the percentage of SEC enforcement actions targeting to foreign firms as a percentage of enforcement by type. The deflator used for Insider Trading and Restatements come from the SEC annual reports (under Insider Trading and Issuer Financial Reporting and Disclosure). FCPA figures are from the SEC's website available here: http://www.sec.gov/spotlight/fcpa/fcpa-cases.shtml. The Restatements are shown in blue on the secondary axis (also in blue).

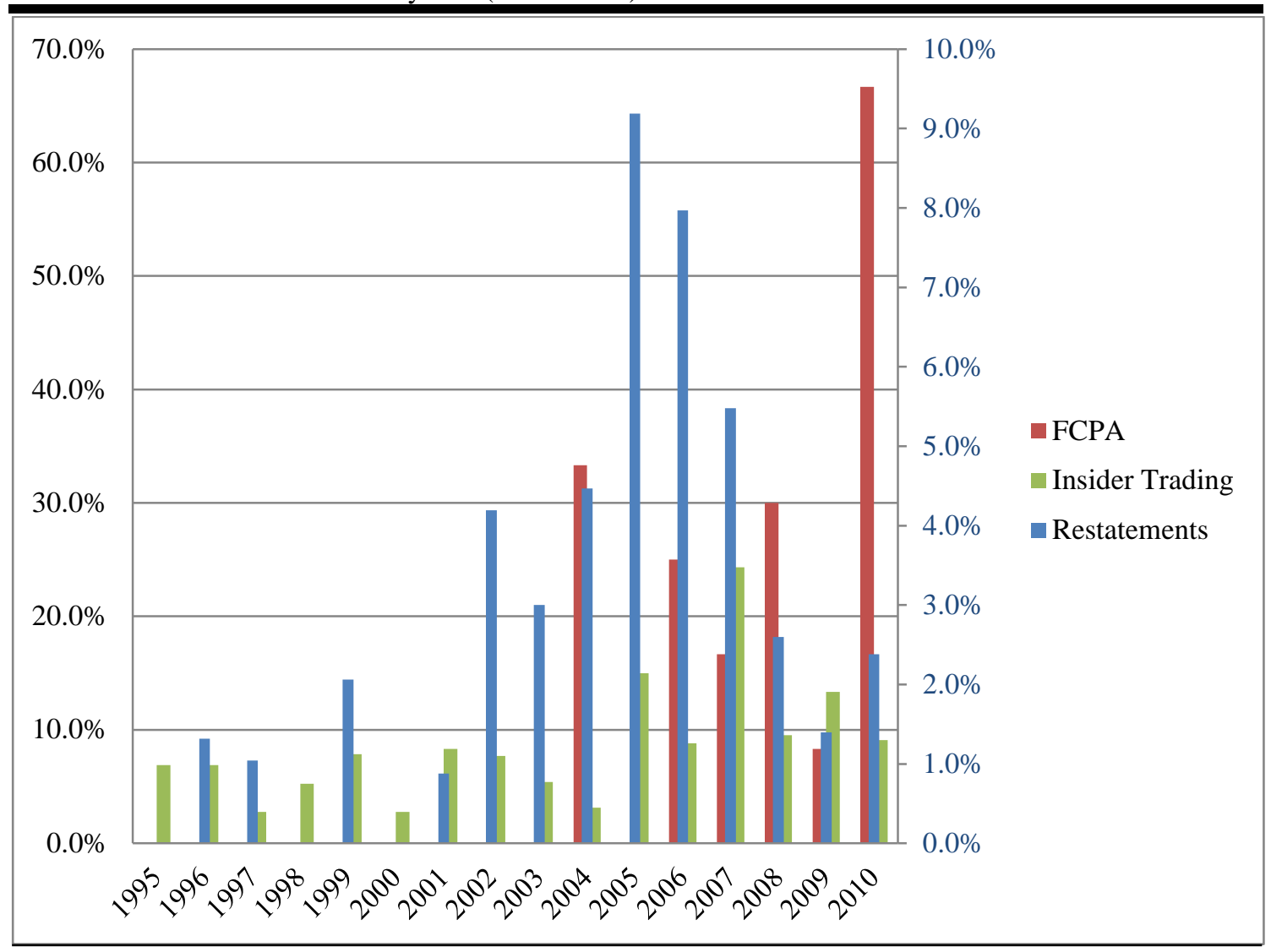


Figure 2: Portfolio Returns

Figure 2a shows the market-adjusted returns to the non-target portfolio of firms around the announcement of enforcement actions by the SEC against foreign firms. The 171 data points are represented by different symbols which denote enforcement type. Figure $2 b$ shows the distribution of the SEC enforcement announcements throughout the year.

Figure 2a: by Event Type

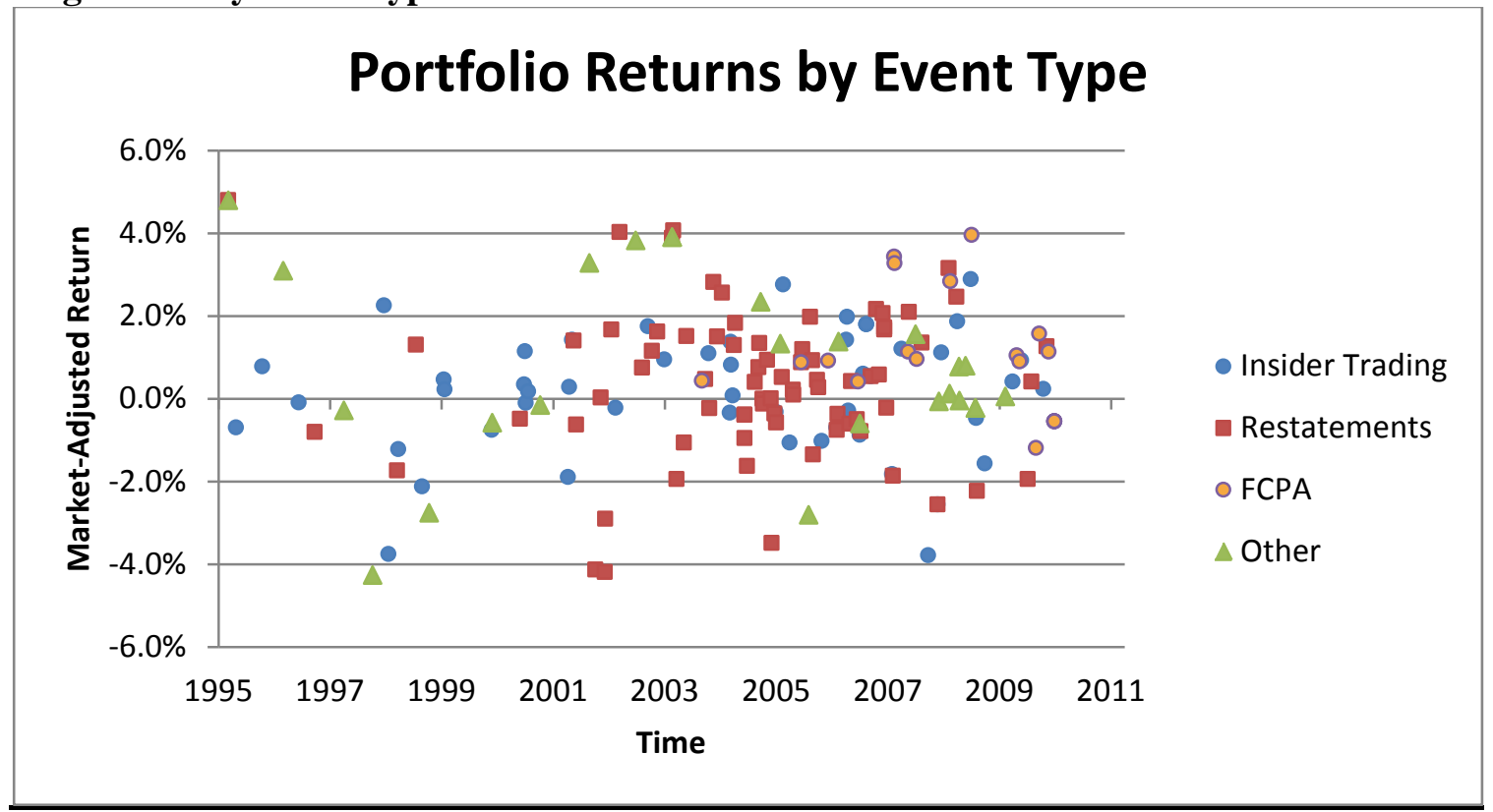

Figure 2b: by Month

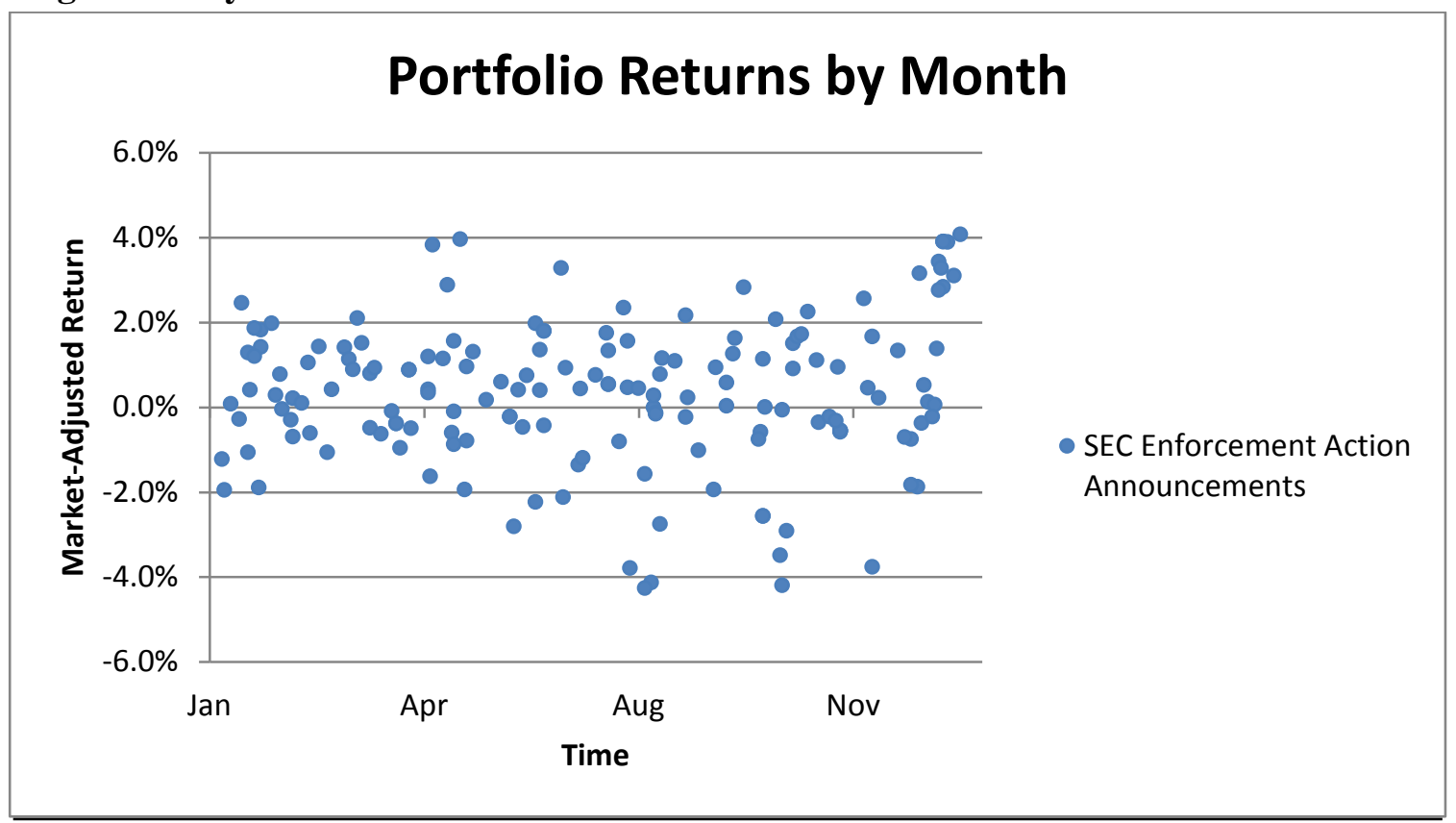




\section{Figure 3: SEC Enforcement across the Globe}

Figure 3 shows the percent of firm-years with an SEC enforcement action by country. Darker colors indicate higher proportions of enforcement.

Cyprus is excluded because of its extreme value (66.67\%). A legend is provided at the bottom of the figure.

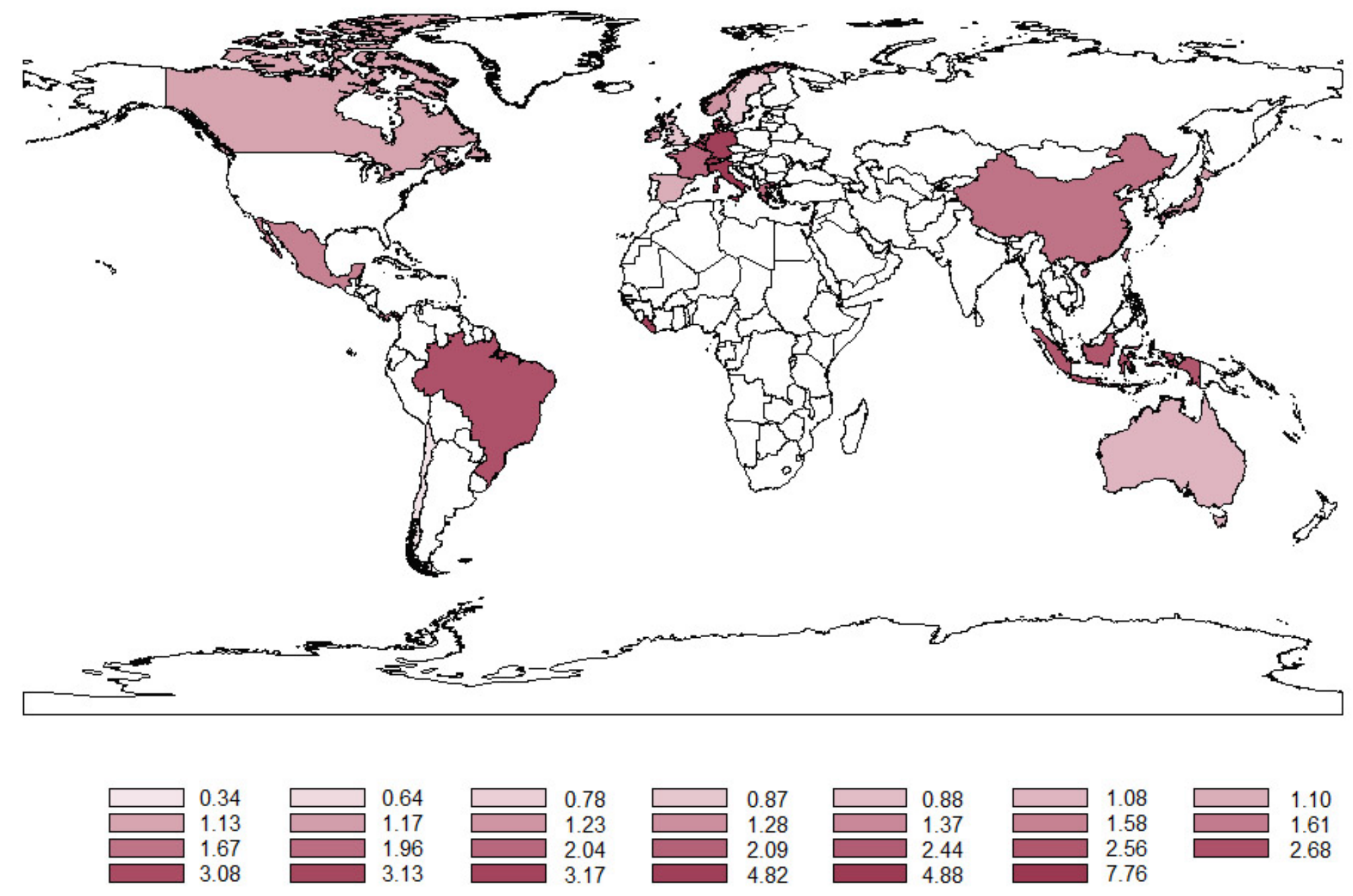




\section{BIBLIOGRAPHY}

Amihud, Y., Mendelson, H., 1986. Asset pricing and the bid-ask spread. Journal of Financial Economics. 17, 223-249.

Armstrong, C., Barth, M., Jagolinzer, A. and Riedl, E., 2010. Market Reaction to the Adoption of IFRS in Europe. The Accounting Review. 85, 31-61.

Ayyagari, M., 2004. International corporate governance: A study of complementarities and convergence. Ph.D. dissertation, University of Maryland.

Ball, R. and Shivakumar, L. 2005. Earnings quality in U.K. private firms. Journal of Accounting and Economics. 39, 83-128.

Bank of New York, 2009. The depositary receipt markets: 2009 mid-year review. Available at: http://www.adrbnymellon.com/files/MS26436.pdf.

Becker, G., 1968. Crime and punishment: an economic approach. Journal of Political Economy. 109, 811-841.

Benos, E., Weisbach, M., 2004. Private benefits and cross-listings in the United States. Emerging Markets Review. 5, 217-240.

Berger, P., Li, F., Wong, F. 2006. The impact of Sarbanes-Oxley on cross-listed companies. Working paper, University of Chicago.

Bhattacharaya, U., 2006. Enforcement and its impact on cost of equity and liquidity of the market. Task Force to Modernize Securities Legislation in Canada. , and Daouk, H., 2002. The world price of insider trading. Journal of Finance. 57, 75108.

Burgstahler, D., Hail, L. and Leuz, C., 2006. The importance of reporting incentives: Earnings management in European private and public firms. The Accounting Review. 81, 9831016.

Christensen, H. B., Hail, L., and Leuz, C., 2011. Capital-Market Effects of Securities Regulation: The Role of Implementation and Enforcement. Available at SSRN: http://ssrn.com/abstract=1745105.

Cameron, C. A., Gelbach, J., and Miller, D., 2006. Robust inference with multi-way clustering. NBER Technical Working Paper No. 327.

Coffee, J.C., 1984. Market failure and the economic case for a mandatory disclosure system. Virginia Law Review 70, 717-753.

2000. Racing towards the top?: The impact of cross-listings and stock market competition on international corporate governance. Columbia Law Review. 102, 17571831. 
, 2007. Law and the Market: The Impact of enforcement. Columbia Law and Economics Working Paper No. 304. Available at SSRN:

http://ssrn.com/abstract=967482.

, 1999. The future as history: the prospects for global convergence in corporate governance and its implications. Northwestern University Law Review. 93, 641-707.

Daske, H., Hail, L., Leuz, C., and Verdi, R. 2008. Mandatory IFRS reporting around the world: Early evidence on the economic consequences. Journal of Accounting Research, 46(5), 1085-1142.3

Doidge, C., 2004. U.S. cross-listings and the private benefits of control: evidence from dual-class firms. Journal of Financial Economics. 72, 519-553.

, Karolyi, G.A., Stulz, R., 2004. Why are foreign firms listed in the U.S. worth more? Journal of Financial Economics. 71, 205-238.

, Karolyi, G.A., Stulz, R., 2009. Has New York become less competitive than London in global markets? Evaluating foreign listing choices over time. Journal of Financial Economics 91, 253-277.

, Karolyi, A., Stulz, R., 2007. Why do countries matter so much for corporate governance? Journal of Financial Economics. 86, 1-39.

, Karolyi, G.A., Lins,K., Miller, D., Stulz, R., 2009. Private benefits of control, ownership, and the cross-listing decision. Journal of Finance. 64, 425-466.

Djankov, S., Lopez de Silanes, F., La Porta, R, Shleifer, A. 2005 The law and economics of selfdealing. Available at: http://ssrn.com/abstract=864645 or doi:10.2139/ssrn.864645.

Errunza, V., and Losq, E., 1985. International asset pricing under mild segmentation: Theory and test. The Journal of Finance. 40(1), 105-124.

Fama, E., French, K., 1992a. The cross-section of expected stock returns. Journal of Finance. 47, 427-465.

, 1992b. Common risk factors in the returns on stocks and bonds. Journal of Financial Economics. 33, 3-56.

, MacBeth, J., 1973. Risk, return, and equilibrium: empirical tests. Journal of Political Economy. 81, 607-636.

Ferson, W., Harvey, C., 1999. Conditioning variables and the cross-section of stock returns. 54, 1235-1360.

Firth D. Bias reduction of maximum likelihood estimates. Biometrika 1993; 80:27-38.

Foerster, S., Karolyi, G.A., 1999. The effects of market segmentation and investor recognition on asset prices: evidence from foreign stocks listing in the US. Journal of Finance. 54, 9811013. 
Karolyi, G.A., 2000. The long-run performance of global equity offerings. Journal of Financial and Quantitative Analysis. 35, 499-528.

Friedman, F. B., Jacobs, E, Macel IV, S. C., 2002. Taking stock of information sharing in securities enforcement matters. Journal of Financial Crime, 10, 37-53.

Frost C., Kinney J. 1996. Disclosure choices of foreign registrants in the United States. Journal of Accounting Research. 34, 67-84.

Gagnon, L., Karolyi, A., 2011. The economic consequences of the U.S. Supreme Court's Morrison v. National Australia Bank decision for foreign stocks cross-listed in U.S. markets. Working paper, Cornell University. Available at http://papers.ssrn.com/sol3/papers.cfm?abstract_id=1961178.

Gande, A., Miller, D. 2011. Why do U.S. securities laws matter to non-U.S. firms? Evidence from private class-action lawsuits. Available at: http://papers.ssrn.com/sol3/papers.cfm?abstract_id=1939059.

Gordon, E., Jorgensen, B., Linthicum, C. 2011. Could IFRS replace US GAAP? A comparison of earnings attributes and informativeness in the US market. Working paper.

Gow, I., Ormazabal, G., Taylor, D., 2010. Correcting for cross-sectional and time-series dependence in accounting research. The Accounting Review. 85, 483-512.

Gozzi, J., Levine, R., and Schmukler, S., 2008. Internationalization and the evolution of corporate valuation. Journal of Financial Economics. 88(3), 607-632

Gleason, C., Jenkins, N., Johnson, W., 2008. The contagion effects of accounting restatements. The Accounting Review. 83, 83-110.

Hail, L., Leuz, C., 2009. Cost of capital effects and changes in growth expectations around U.S. cross-listings. Journal of Financial Economics. 93, 428-454. , and _ _ 2006. International differences in the cost of equity capital: Do legal institutions and securities regulation matter?. Journal of Accounting Research. 44, 485531.

Hayne, C., 1995. The Information Content of Losses. Journal of Accounting \& Economics, 20, 125-153.

Heinze, G., Schemper, M. 2002. A solution to the problem of separation in logistic regression. Statistics in Medicine. 21 2409-2419.

Hennes, K., Leone, A., Miller, B., 2008. The importance of distinguishing errors from irregularities in restatement research: The case of restatements and CEO/CFO turnover. The Accounting Review. 83, 1487-1519.

Holthausen, R. W., 2009. Accounting Standards, Financial Reporting Outcomes, and Enforcement.’ Journal of Accounting Research. 47, 447-458. 
ideaCity06 Conference, 2006. Conference presentation, Toronto, CA. Available at: http://sciencestage.com/v/34634/lord-conrad-black-at-ideacity06-part-1-of-3.html.

Interim Report of the Committee on Capital Markets Regulation, 2006. Available at: http://www.capmktsreg.org/pdfs/11.30Committee_Interim_ReportREV2.pdf.

Jackson, H., 2007. Variation in the intensity of financial regulation: Preliminary evidence and potential implications. Yale Journal on Regulation. 24 (2), 253-291.

Jennings, J., Kedia, S., Rajgopal, S., 2011. The deterrence effects of SEC enforcement and class action litigation. Available at SSRN: http://ssrn.com/abstract=1868578.

Kadlec, G., McConnell, J. 1994. The effect of market segmentation and illiquidity on asset prices: Evidence from exchange listings. The Journal of Finance. 49, 611-636.

Karolyi, G.A., Stulz, R., 2003. Are financial assets priced locally or globally? In: Constantinides, G., Harris, M., Stulz, R. (Eds.), Handbook of the Economics of Finance. North-Holland, Amsterdam, pp. 975-1020.

, 1998. Why do companies list shares abroad? A survey of the evidence and its managerial implications. Financial Markets, Institutions and Instruments. 7, 1-60.

, 2006. The world of cross-listings and cross-listings of the world: challenging conventional wisdom. Review of Finance. 10, 99-152.

, 2010. Corporate governance, agency problems and international cross-listings: A defense of the bonding hypothesis. Working paper, Cornell University.

Kaufmann, D., Kraay, A., Mastruzzi, M. 2010. The worldwide governance indicators : a summary of methodology, data and analytical issues. World Bank Policy Research Working Paper No. 5430. Available at: http://papers.ssrn.com/sol3/papers.cfm?abstract_id=1682130.

Kedia, S., Rajgopal, S., 2011. Do the SEC’s enforcement preferences affect corporate misconduct? Journal of Accounting and Economics. (forthcoming).

Kim, I., Skinner, D., 2011. Measuring securities litigation risk. Journal of Accounting and Economics. Forthcoming.

La Porta, R., Lopez-de-Silanes, F., Shleifer, A., 2006. What works in securities laws? Journal of Finance. 61, 1-32.

Lang, M., Lins, K., Miller, D., 2003. ADRs, analysts, and accuracy: does cross-listing in the United States improve a firm's information environment and increase market value? Journal of Accounting Research. 41, 317-345.

Raedy, J. S. and Yetman, M., 2003. How Representative Are Firms That Are CrossListed in the United States? An Analysis of Accounting Quality. Journal of Accounting Research. 41, 363-386. 
Lel, U., Miller, D. 2008. International cross-listing, firm performance, and top management turnover: A test of the bonding hypothesis. The Journal of Finance. 63, 1897-1937.

Leuz, C., 2006 Cross-listing, bonding and firms' reporting incentives: A discussion of Lang, Raedy and Wilson (2006)*. Journal of Accounting \& Economics, 42, 285.

, 2007. Was the Sarbanes-Oxley Act of 2002 really this costly? A discussion of evidence from event returns and going-private decisions*. Journal of Accounting and Economics. 44, 146-165.

, 2010. Different approaches to corporate reporting regulation: How jurisdictions differ and why. Chicago Booth Initiative on Global Markets Research Paper No. 53; ECGI Law Working Paper No. 156/2010. Available at SSRN:

http://ssrn.com/abstract=1581472.

, and P. Wysocki, 2008, Economic consequences of financial reporting and disclosure regulation: A review and suggestions for future research, Working paper, University of Chicago.

Licht, A., 2003. Cross-listing and corporate governance: Bonding or avoiding? Chicago Journal of International Law. 4, 141-163.

, Li, X., Siegel, J., 2011. What makes the bonding stick? A natural experiment involving the supreme court and cross-listed firms. Working paper, Harvard Business School. Available at SSRN: http://papers.ssrn.com/sol3/papers.cfm?abstract_id=1744905.

Mann, M., Barry, W., 2005. Developments in the internationalization of securities enforcement. The International Lawyer. 39 (3), 667-696.

Merton, R., 1987. A simple model of capital market equilibrium with incomplete information. Journal of Finance. 42, 483-510.

Miller, D., 1999. The market reaction to international cross-listings: evidence from depositary receipts. Journal of Financial Economics. 51, 103-123.

Mulherin, J.H., 2007. Measuring the costs and benefits of regulation: Conceptual issues in securities regulation. 13, 421-437.

Muradoglu, Y. and Huskey, J., 2008. The Impact of SEC litigation on firm value. Available at SSRN: http://ssrn.com/abstract=1094948.

Petersen, M., 2009, Estimating standard errors in finance panel data sets: Comparing approaches, Review of Financial Studies 22, 435-480.

Piotroski, J., Srinivasan, S., 2008. Regulation and bonding: the Sarbanes-Oxley Act and the flow of international listings. Journal of Accounting Research. 46, 383-425.

Posner, R. 1974. Theories of economic regulation, Bell Journal of Economics and Management Science. 5 (2), 335-358. 
PriceWaterhouseCoopers., 2004. 2003 PriceWaterhouseCoopers LLP Securities Litigation Study. Available at: http://10b5.pwc.com/PDF/2003_STUDY_FINAL.PDF.

Reese, W., Weisbach, M., 2002. Protection of minority shareholder interests, cross-listings in the United States, and subsequent equity offerings. Journal of Financial Economics. 66, 65104.

Salavei, K., Golec, J., Harding, J., 2009. Litigation risk and market reaction to restatements. Available at SSRN: http://ssrn.com/abstract=1505119.

Schipper, K., and Thompson, R., 1983. Evidence on the capitalized value of merger activity for acquiring firms. Journal of Financial Economics. 11, 85-119.

Schrand, C., Zechman, S., 2009. Executive overconfidence and the slippery slope to financial misreporting. Available at: http://papers.ssrn.com/sol3/papers.cfm?abstract_id=1265631.

Sefcik, S., Thompson, R., 1986. An approach to statistical inference in cross-sectional models with security abnormal returns as dependent variable. Journal of Accounting

Research. 24, 316-334.

Sherwin E. 2005. The cost-benefit analysis of financial regulation: What the sec ignores in the rulemaking process, why it matters, and what to do about it. Working Paper, Harvard University. Available at: http://www.law.harvard.edu/faculty/hjackson/pdfs/CBA.article.doc.pdf.

Shleifer, A., 2005. Understanding regulation. European Financial Managemanet. 11(4), 439-451.

Shnitser, N., 2010. A free pass for foreign firms? An assessment of SEC and private enforcement against foreign issuers. Yale Law Journal, 119, 1638-1701.

Siegel, J., 2005.Can foreign firms bond themselves effectively by renting U.S. securities laws? Journal of Financial Economics 75, 319-359.

Stigler, G., 1964, Public regulation of the securities market. Journal of Business 37, 117-142. 1971, The theory of economic regulation. Bell Journal of Economics and Management Science 2, 3-21.

Stulz, R., 1999. Globalization, corporate finance, and the cost of capital. Journal of Applied Corporate Finance. 12, 8-25.

, 2009. Securities laws, disclosure, and national capital markets in the age of financial globalization. Journal of Accounting Research, 47, 349-390.

USA Patriot Act of 2001. Uniting and Strengthening America by Providing Appropriate Tools Required to Intercept and Obstruct Terrorism (USA PATRIOT ACT) Act of 2001. Available from the Library of Congress at: http://thomas.loc.gov/cgibin/bdquery/z?d107:HR03162:\%5D.

Vaknin, S., 2002. The Future of the SEC: Interview with Gary Goodenow. Available at: http://samvak.tripod.com/sec.html. 
Watts, R., J. Zimmerman. 1978. Towards a positive theory of the determination of accounting standards. The Accounting Review 53, 112-134.

White, H., 1980. Heteroskedasticity-consistent covariance matrix estimator and a direct test for heteroskedasticity. Econometrica. 48, 817-38.

Zhu, Q., 2010. The home stigma: Adverse selection in ADRs and the home capital market environment. Available at SSRN: http://ssrn.com/abstract=1537502.

Zimring, F. and Hawkins, G. 1973. Deterrence: The legal threat in crime control: Journal of Criminal Justice. 1, 168-170.

Zingales, L., 2004. The costs and benefits of financial market regulation. ECGI/University of Chicago Working Paper, Available here:

http://www.cgscenter.org/library/CorpGovCompValue/CostbenefitofFinMarketEvaluatio n.pdf.

, 2007. Is the U.S. capital market losing its competitive edge?. ECGI/University of Chicago Working Paper, Available here:

http://papers.ssrn.com/sol3/papers.cfm?abstract_id=1028701.

, 2009, The future of securities regulation, Journal of Accounting Research 47, 391425. 